\title{
Perspectives of RAS and RHEB GTPase Signaling Pathways in Regenerating Brain Neurons
}

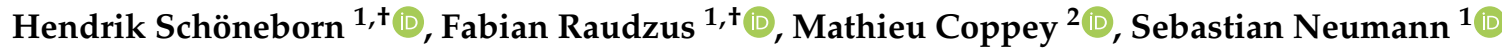 \\ and Rolf Heumann ${ }^{1, *}$ \\ 1 Ruhr-Universität Bochum, Faculty of Chemistry and Biochemistry, \\ Department of Biochemistry II-Molecular Neurobiochemistry, 44801 Bochum, Germany; \\ hendrik.schoeneborn@ruhr-uni-bochum.de (H.S.); fabian.raudzus@ruhr-uni-bochum.de (F.R.); \\ sebastian.neumann@ruhr-uni-bochum.de (S.N.) \\ 2 Laboratoire Physico-Chimie, Institut Curie, CNRS UMR168, PSL Research University, \\ Universite Pierre et Marie Curie-Paris, 75005 Paris, France; mathieu.coppey@curie.fr \\ * Correspondence: rolf.heumann@ruhr-uni-bochum.de; Tel.: +49-234-32-28230 \\ + These authors contributed equally to this work.
}

Received: 14 November 2018; Accepted: 13 December 2018; Published: 14 December 2018

\begin{abstract}
Cellular activation of RAS GTPases into the GTP-binding "ON" state is a key switch for regulating brain functions. Molecular protein structural elements of rat sarcoma (RAS) and RAS homolog protein enriched in brain (RHEB) GTPases involved in this switch are discussed including their subcellular membrane localization for triggering specific signaling pathways resulting in regulation of synaptic connectivity, axonal growth, differentiation, migration, cytoskeletal dynamics, neural protection, and apoptosis. A beneficial role of neuronal H-RAS activity is suggested from cellular and animal models of neurodegenerative diseases. Recent experiments on optogenetic regulation offer insights into the spatiotemporal aspects controlling RAS/mitogen activated protein kinase (MAPK) or phosphoinositide-3 kinase (PI3K) pathways. As optogenetic manipulation of cellular signaling in deep brain regions critically requires penetration of light through large distances of absorbing tissue, we discuss magnetic guidance of re-growing axons as a complementary approach. In Parkinson's disease, dopaminergic neuronal cell bodies degenerate in the substantia nigra. Current human trials of stem cell-derived dopaminergic neurons must take into account the inability of neuronal axons navigating over a large distance from the grafted site into striatal target regions. Grafting dopaminergic precursor neurons directly into the degenerating substantia nigra is discussed as a novel concept aiming to guide axonal growth by activating GTPase signaling through protein-functionalized intracellular magnetic nanoparticles responding to external magnets.
\end{abstract}

Keywords: RAS GTPase; RHEB GTPase; Parkinson's disease; survival; axonal guidance; brain regeneration; optogenetics; magnetogenetics; nanoparticle; Magneto Protein Therapy

\section{Introduction}

The RAS superfamily is a class of small guanosine triphosphatases (GTPases) comprising more than 150 human members. Based on functional and sequence similarities it is subdivided into the five major subclasses RAS, RHO, RAB, RAN, and ARF [1,2]. In general, RAS signaling is tightly controlled, whereas perturbations in RAS signaling result in malignant tumor formation. In the 1960s, RAS genes were first identified as retroviral oncogenes of Harvey [3] and Kirsten [4] rat sarcoma (H-RAS, K-RAS) viruses. In particular, by identifying constitutively active RAS mutations in human tumors, a new era dawned on RAS research [5]. 
The RAS homolog protein enriched in brain (RHEB) is a member of the RAS subclass that is highly conserved in different organisms from yeast to human [6]. In mammalians, two different RHEB genes have yet been identified. The gene products of RHEB1 (from here on RHEB) and RHEB2 (also RHEBL1) share 54\% identity and 74\% similarity and it is hypothesized that both proteins perform similar functions [7]. RHEB is expressed in various human tissues whereas RHEB2 is mainly expressed in the brain, especially in the cerebral cortex, occipital pole, frontal and temporal lobes [8]. RHEB was originally discovered in rat brain as an immediate-early gene, whose cellular level is rapidly increased by high frequency-induced synaptic activity in a N-methyl-D-aspartate (NMDA)-dependent manner [9].

In this review, we compare RAS and RHEB GTPases as switch proteins controlling major brain functions such as neuronal survival and regeneration, synaptic connectivity, growth, differentiation, migration, and cytoskeletal integrity.

After reviewing structural key elements of proteins involved in this switch function and its regulation of downstream intracellular signaling, we will put into focus the importance of subcellular membrane localization culminating in recent aspects of non-invasive optogenetic remote controlling of GTPase signaling after exposing light to brain neurons. Finally, we concentrate on the advances in the fields of manipulating intracellular RAS signaling pathways by generating magnetic guidance cues in neuronal axons containing functionalized intracellular paramagnetic nanoparticles. New therapeutic horizons and possible limits of these novel approaches are critically discussed.

\section{Structural Basis of the RAS and RHEB GTPase Switch}

Small GTPases share common biochemical mechanisms and act as conserved binary molecular switches cycling between an active GTP-bound and an inactive GDP-bound state (Figure 1) [10]. Functioning as monomeric or dimeric/oligomeric $G$ proteins [11,12], post-translational modifications of RAS and RHEB specify their subcellular localization resulting in the activation of specific regulators and effectors in a cell type-dependent manner [13-16]. The proteins of the RAS family of GTPases (H-RAS, N-RAS, and K-RAS) are highly conserved with minor differences in the membrane anchoring hypervariable region (HVR) at the C-terminus [13].

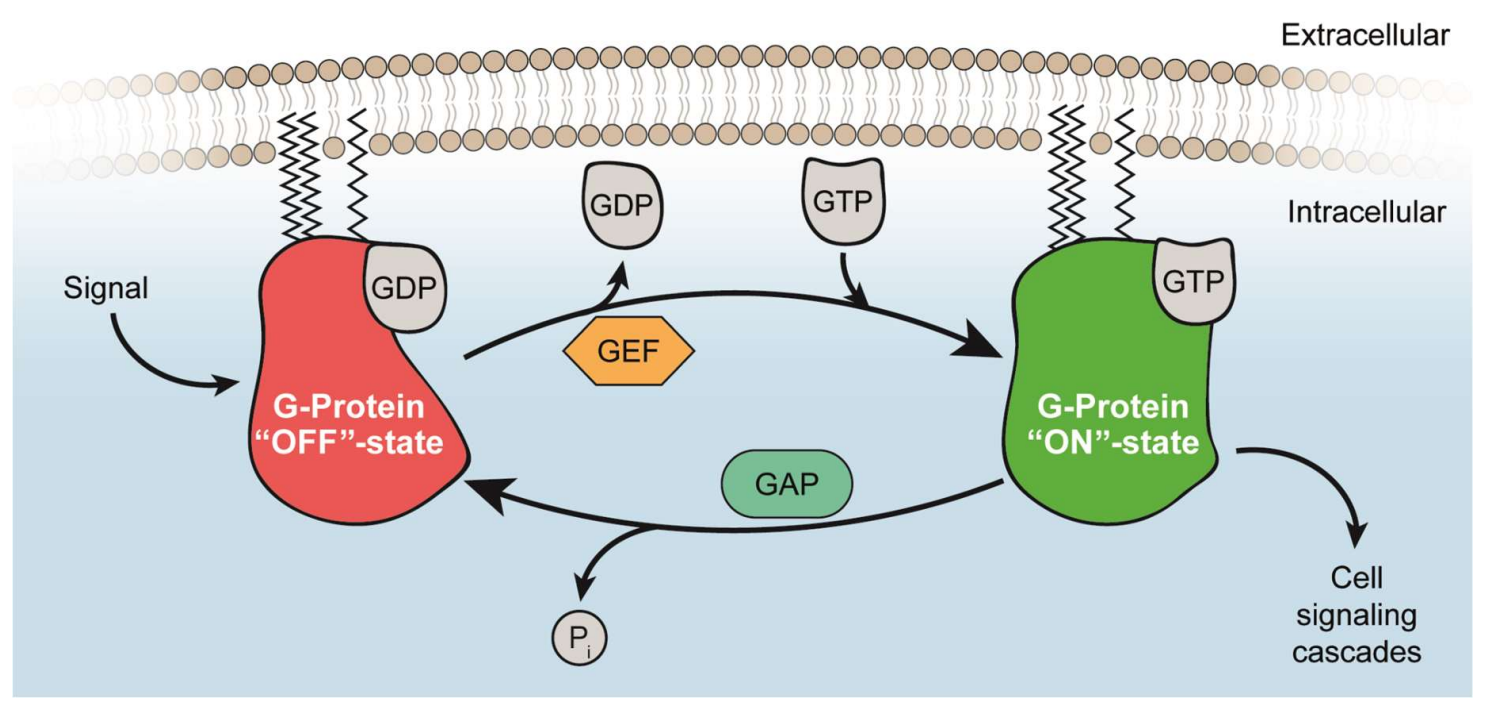

Figure 1. GTPase cycling between GTP-bound "ON" state and GDP-bound "OFF" state. Upon an external signal, a guanine nucleotide exchange factor (GEF) is activating small GTPases (here H-RAS) by exchanging GDP to GTP and thereby modulating cell signaling cascades. To return into the "OFF" state, GTPase-activating proteins (GAPs) accelerate GTP hydrolysis to GDP. 


\subsection{Guanine Nucleotide-Binding}

The first 169 amino acids of RAS-related proteins fold into a globular, hydrophilic protein and contain a guanine nucleotide (G)-binding site that consists of a mixed six-stranded $\beta$-sheet and five helices executing the central function of nucleotide-binding and hydrolysis [13]. Binding is achieved by the interaction of the nucleotide base with the N/TKXD motif and with the $\beta, \gamma$-phosphates of the conserved phosphate-binding loop (P loop), referred to as GXXXXGKS/T motif. The two nucleotide-bound states are defined by changes in the "switch regions", first observed in RAS. In the GTP-bound state, two hydrogen bonds from $\gamma$-phosphate oxygens link to main chain $\mathrm{NH}$-groups of $\mathrm{Thr}^{35}$ and Gly ${ }^{60}$ residues in the switch I and II region of RAS. In particular, $\mathrm{Thr}^{35}$ is involved in $\mathrm{Mg}^{2+}$-binding whereas $\mathrm{Gly}^{60}$ is part of a DXXG motif involved in nucleotide binding. The conformational change is akin to a loaded-spring mechanism due to relaxing switches into the GDP-specific conformation on $\gamma$-phosphate release after GTP hydrolysis [10,17].

\subsection{Activation of RAS and RHEB by GEFs}

RAS is activated by guanine nucleotide exchange factors (GEFs) resulting in increased relative levels of GTP-bound RAS [18]. Within a subfamily, GEFs are highly conserved, but in contrast to the guanine nucleotide binding protein (GNBP), structures vary across different families. GEFs for RAS have a cell division cycle 25 (CDC25) domain that forms a trimeric GNBP-nucleotide-GEF state and subsequently results in an intermediary binary complex with RAS having an empty nucleotide-binding site. Thus, the nucleotide-free state is stabilized and preferential rebinding of GTP occurs due to the 10-fold higher concentration of GTP as compared to GDP in the cell.

In detail, GEFs interact with both switch regions and insert residues into the RAS GTPase in close proximity to the $\mathrm{P}$ loop and $\mathrm{Mg}^{2+}$-binding area to inhibit metal ion- and phosphate-binding. $\mathrm{Mg}^{2+}$ is released from its position by $\mathrm{Ala}^{59}$ or by GEF amino acid residues. By disturbing residues of the P loop, $\mathrm{Lys}^{16}$ is reoriented towards carboxylates of $\mathrm{Asp}^{57}$ or Glu ${ }^{62}$ from the switch II region. All together, these conformational changes push the switch II region towards the nucleotide-binding site and switch I outwards of its original position. Thereby, the interaction surface in the phosphate-binding region is perturbed while leaving the base-binding region mostly unperturbed. Consequently, GDP is released, and the nucleotide-free state is stabilized. Subsequently, the entering nucleotide binds and starts to displace the GEF thereby terminating the nucleotide exchange cycle $[10,19]$.

Although there is a high sequence identity between RAS and RHEB, different mechanisms for nucleotide exchange exist. It could be shown that translationally controlled tumor protein (TCTP) is essential for growth and proliferation through regulation of RHEB GTPase in Drosophila [20]. Even though, RHEB may not possess a genuine GEF, as basal nucleotide exchange rates are high enough to sufficiently load RHEB with GTP [21].

\subsection{Inactivation of $R A S$ and RHEB by GAPs}

To switch from the active RAS GTP-bound to the inactive RAS GDP-bound conformation, GTPase-activating proteins (GAPs) accelerate the GTP hydrolysis by several orders of magnitudes so that GDP and $P_{\mathrm{i}}$ are released leading to a complete shutdown of signaling within minutes $[10,18,22]$. Mutations of $\mathrm{Gly}^{12}$, Gly ${ }^{13}$, and $\mathrm{Glu}^{61}$ near the $\gamma$-phosphate in the active site of RAS are crucial for RAS-triggered tumors. Studies performing structural analysis of the RAS-GAP complex in presence of AlF $_{x}$ show that GAP stabilizes the GDP-AlF $x_{x}$ state by binding to the catalytic glutamine of the switch II region of RAS. Moreover, for achieving its full activity, GAPs insert an arginine ("arginine finger") into the active site of the GTPase. Oncogenic mutants of RAS have lost the ability to hydrolyze GTP and thereby remain in a permanently active state [10].

RHEB has been shown to be inactivated by tuberin (TSC2) forming the tuberous sclerosis complex (TSC) together with Hamartin (TSC1). In contrast to RAS-GAP containing an arginine finger, RHEB-GTP-hydrolysis is catalyzed by the presence of an "asparagine thumb" in tuberin [21]. 
This active-site asparagine corresponds to Asn ${ }^{1601}$ in TSC2, which is mutated in human disease and is also required for TSC2-GAP activity [23].

Taking together, the "ON" / "OFF" state level of RAS is determined by its GEF and GAP activity, while the RHEB "ON" / "OFF" state level is mainly determined by TSC-GAP activities.

\subsection{Membrane Anchoring of RAS and RHEB}

The H-, K- and N-RAS variants differ in the 25 amino acid-comprising HVR containing a tetrapeptide sequence termed as "CAAX ( $\mathrm{C}=\mathrm{Cys}, \mathrm{A}=$ aliphatic, and $\mathrm{X}=$ any amino acid $)$ motif" at the C-terminus. A part of the post-translational modifications takes place at the CAAX motif leading to trafficking of synthesized RAS from the cytosolic surface of the endoplasmatic reticulum (ER) to the inner surface of the plasma membrane for its anchoring [22]. First, a 15-carbon isoprenyl group is irreversibly attached to RAS ${ }^{\mathrm{C} 186}$ by farnesyl transferase. At the cytoplasmic ER surface, RAS-converting enzyme (RCE1) and isoprenylcysteine carboxylmethyl transferase (ICMT) mediate the cleavage of AAX tripeptide and carboxylmethylation. For cytoplasmic membrane localization and cellular function of RAS both farnesylation and palmitoylation are required. In addition, H-RAS is palmitoylated on Cys ${ }^{181}$ and Cys $^{184}$ and N-RAS on Cys ${ }^{181}$ in the HVR by palmitoyl transferase at the Golgi apparatus for vesicular transport to the plasma membrane [13].

K-RAS4B is provided with a polybasic region of lysines that interacts with negatively charged lipid head groups of the membrane [24], and even microtubules [25]. Thissen et al. showed the requirement of prenylation and methylation of K-RAS4B for this interaction [26]. Schmick et al. identified the localization of K-RAS to the plasma membrane by solubilization, trapping, and vesicular transport of K-RAS by PDE $\delta$ and ARL-2GTP [27]. Ubiquitinated plasma membrane-anchored RAS is unable to activate MAPK pathway and is not targeted to endosomes. [28].

In contrast to RAS which triggers signaling from the inner face of the cytoplasmic membrane, signaling active RHEB is located at endomembrane compartments such as the endoplasmatic reticulum, the Golgi apparatus, and lysosomes [8,29-31]. Due to a C-terminal CAAX motif, RHEB is farnesylated at the cysteine residue of the motif by a protein farnesyltransferase which enhances membrane association $[29,31]$.

\section{Intracellular RAS and RHEB Effector Mechanisms}

\subsection{RAS/RAF Effector Mechanisms}

Effectors for GTP-binding proteins prefer binding to the GTP-bound state involving the switch regions of GNBP which is supported by their structure (Figure 2). The RAS effector rapidly accelerated fibrosarcoma (RAF) binds selectively to the GTP-bound RAS through a ubiquitin-fold domain [10]. RAF is a serine/threonine kinase and is held in an auto-inhibited conformation by the binding of 14-3-3 to phosphorylated $\operatorname{Ser}^{259}$ of the RAF amino-terminus [32]. Upon activation by mitogens, GTP-loaded RAS interacts with RAF proteins via RAS-binding domains (RBDs) leading to plasma membrane recruitment of RAF [23]. Autoinhibition is terminated by the interaction of RAS and RAF and correlating with $\operatorname{Ser}^{259}$ dephosphorylation and release of inhibitory 14-3-3 [33]. At the membrane, RAF contacts kinases such as SRC family kinases (SFKs) and casein kinase 2 (CK2), which phosphorylate activating sites in the negatively charged $\mathrm{N}$-terminal region. RAS nanoclusters and membrane binding augment the effective RAF concentration thus contributing to RAF dimerization supported by 14-3-3 and its phosphorylated Ser ${ }^{621}$ at the carboxy-terminal tail $[34,35]$. By dimerization, the catalytic activity of RAF is induced, MEK recruited and phosphorylated, thereby signaling down the three-tiered MAPK modules. A negative feedback loop is implemented by extracellular-signal-regulated kinase (ERK, also referred to as MAPK) signaling through phosphorylation of inhibitory sites in distinct regions of activated RAF, resulting in release from activated RAS and disruption of RAF dimers. RAF-activating and ERK-targeted phosphorylation sites are dephosphorylated to recycle RAF proteins for new activation cycles. Regulation of kinase suppressor of RAS (KSR) occurs in parallel steps. 
While inactive KSR proteins stay in the cytosol due to the interaction with inhibitory 14-3-3 proteins in their N-terminal region, KSR and MEK form constitutive complexes. Upon dephosphorylation of Ser ${ }^{406}, 14-3-3$ is released and KSR proteins are anchored in the plasma membrane via conserved area 1 (CA1) and CA3. Heterodimerization of KSR and RAF proteins lead to RAF transactivation and MEK-ERK signaling. Phosphorylation of several sites in RAF and KSR by an ERK-mediated negative feedback loop disrupts RAF-KSR dimers and attenuates the signal. Up to now, it is not known whether the N-terminal region of KSR negatively controls the kinase domain or if it is phosphorylated and contributes to activation [32].

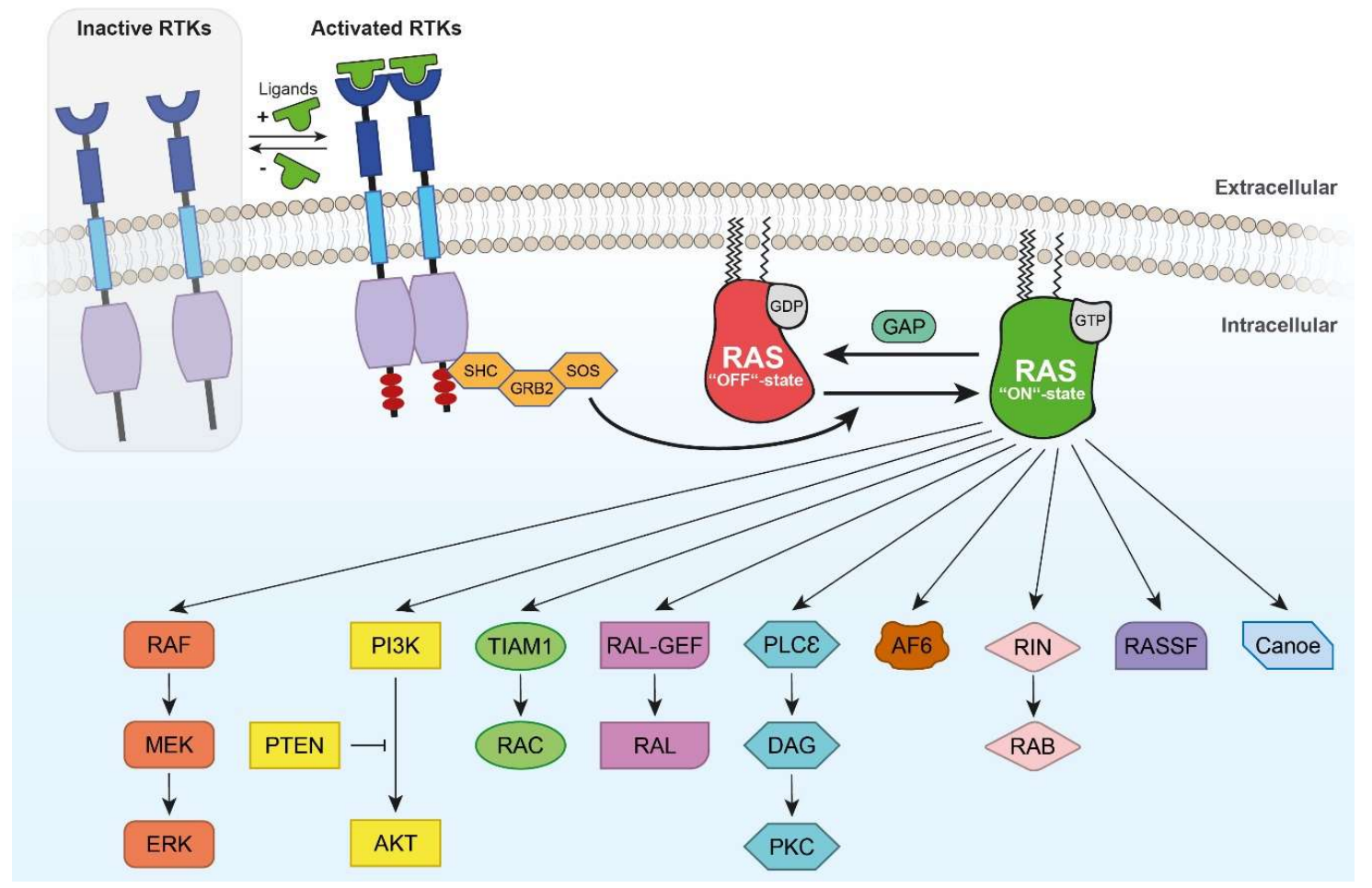

Figure 2. Signaling pathways of RAS GTPase. Receptor tyrosine kinases (RTKs)-mediated activation of RAS in the presence ("+") and absence ("-“) of ligand is shown as an example. However, multiple upstream regulators of RAS exist. The SHC-GRB2-SOS complex promotes the exchange of GDP to GTP and thereby switching RAS GTPase to the active conformation. Hence, signaling is propagated through the diverse pathways of RAS such as the most prominent RAF/MEK/ERK cascade. RAS-mediated PI3-kinase (PI3K) activation results in protein kinase B (AKT) activation, which is inhibited by phosphatase PTEN (illustrated by T-bar). TIAM1/RAC and RAL-GEF/RAL are involved in cytoskeletal dynamics and cell migration. PLC $\varepsilon / D A G / P K C$ is associated with $\mathrm{Ca}^{2+}$-dependent cellular functions. AF6 forms electrical synapses by localizing at gap junctions. RIN controls axonal pathfinding and via RAB endomembrane signaling. RASSF promotes apoptosis and Canoe regulates cellular polarity.

Once activated, MEK phosphorylates ERK which dimerizes and translocates to the nucleus activating the E26 transformation-specific (ETS)-family transcription factors by phosphorylation [1].

\subsection{RHEB Effector Mechanisms}

The active GTP-bound state of RHEB results in an activation of mammalian target of rapamycin (mTOR) by direct interaction of RHEB with the kinase domain of mTOR (Figure 3) [36]. mTOR is a serine/threonine protein kinase of the phosphoinositide 3-kinase-related kinase family. It is highly evolutionarily conserved and coordinates cell metabolism and growth in response to growth factors, nutrients, and energy levels [37,38]. mTOR interacts with several proteins and forms two distinct complexes: mTORC1 consists of the catalytic mTOR, the mammalian lethal with 
SEC13 protein 8 (mLST8/GßL), DEP domain-containing mTOR-interacting protein (DEPTOR), the TTI1/TEL2 complex, regulatory-associated protein of mammalian target of rapamycin (RAPTOR), and proline-rich AKT substrate $40 \mathrm{kDa}$ (PRAS40) [30,39-47]. mLST8, DEPTOR, and TTI1/TEL2 are also part of mTORC2 along with rapamycin-insensitive companion of mTOR (RICTOR), mammalian stress-activated map kinase-interacting protein 1 (mSIN1), and protein observed with RICTOR 1 and 2 (PROTOR1/2) [39,48-50]. mTORC1 directly phosphorylates the eukaryotic translation initiation factor 4E (EIF4E)-binding protein (4E-BP1) and the p70 S6 Kinase (S6K1) [47,51-53]. Due to the phosphorylation of these two translational regulators, cap-dependent translation initiation and by this protein synthesis is promoted [54]. mTORC1 further suppresses autophagy by direct phosphorylation of uncoordinated 51-like kinase (ULK1) and autophagy-related gene 13 (ATG13) [55]. mTORC2 is indicated to regulate actin cytoskeleton dynamics by controlling RHO-GEFs $[48,56]$.

\subsection{Other RAS Effectors}

Besides MAPK signaling, RAS is mainly involved in phosphoinositide-3 kinase (PI3K) pathways. The regulatory unit p85, a member of the PI3K class, binds to phosphotyrosine residues of an activated receptor tyrosine kinase. Then, the catalytic subunit $\mathrm{p} 110$ is activated and phosphorylates phosphatidylinositol-4,5-bisphosphate (PIP2) to phosphatidylinositol-3,4,5-trisphosphate (PIP3). Alternatively, RAS directly activates PI3K by binding to p110 [57]. PIP3 brings phosphoinositidedependent kinase1 (PDK1) and AKT serine/threonine kinase (AKT) in close proximity so that PDK1 phosphorylates AKT. Consequently, AKT is involved in cellular processes of growth and prevention of apoptosis. In contrast, phosphatase PTEN stops this signaling by dephosphorylating PIP3 to PIP2 [58].

In addition, the RAS effectors RAL-GEF, T-lymphoma invasion and metastasis-inducing protein 1 (TIAM), RAS association family (RASSF), Canoe, RAS and RAB interactor 1 (RIN1), phospholipase $\mathrm{C}$ (PLC), Afadin 6 (AF6), and PKC C are briefly described to draw a more complete picture of RAS signaling pathways (Figure 2). RAS-like (RAL) family GTPases are ubiquitously expressed in humans and share $80 \%$ sequence homology to RAS. RAL guanine nucleotide dissociation stimulator (RALGDS), RAL guanine nucleotide dissociation stimulator-like (RGL), RGL2/RLF, and RGL3 have been shown to activate RAS through binding with RAS association (RA) domains [59]. RAL GTPases regulate cell migration, gene expression, actin organization, and exocytosis and mediate activity-dependent growth of postsynaptic membranes [59-63]. Furthermore, RAL and RHEB GTPase are involved in autophagy, aging, and tumor cell invasion [64]. Moreover, RAL GTPase regulates neurite branching through GAP-43 and activity-dependent growth of postsynaptic membranes $[60,65]$. The RAC-GEF TIAM1 links the activation of RAS to RAC [66]. Furthermore, TIAM is involved in neurotrophin-3-induced Schwann cell migration [67] and in RAS-related protein 1 (RAP1)-mediated cell spreading [68]. TIAM1 promotes neuronal protrusion and axon guidance through CDC42 and guidance receptor UNC-40/deleted in colorectal cancer (DCC) [69] as well as neurite extension and cell migration [70,71].

RIN1 is a cytosol-localized specific GEF for RAB5/vacuolar protein sorting-associated protein 21 (VPS21) with RA domain and involved in RAS-regulated endocytosis [72]. RIN2 and RIN3 have been detected in endocytic vesicles. In C. elegans, RIN1 controls neuronal cell migration and axon pathfinding [73]. PLC $\varepsilon$ has been identified as a RAS GTPase binding protein which has been discovered by yeast two hybrid screening. PLC $\varepsilon$ is activated by platelet-derived growth factor (PDGF) and epidermal growth factor (EGF) in a RAS- and RAP1-dependent manner [36,74]. In detail, RAP1 triggers persistent activation of PLC $\varepsilon$ by PDGF, whereas rapid activation of PLC $\varepsilon$ is mediated by RAS [74]. Finally, AF6 and PKC $\zeta$ belong to the family of RAS effectors and are associated with cellular functions such as cell adhesion and transcription [75-78]. AF6 consists of an actin-binding domain, two RA domains at the N-terminus and a PSD-95 Dlg1 ZO-1 (PDZ) domain allowing interaction with the zonula occludens-1 (ZO-1) tight junction protein [79]. In the rodent brain, the scaffolding protein AF6 together with multi-PDZ domain protein 1 (MUPP1) interacts with connexin36 forming electrical synapses by localizing at gap junctions [80]. Strikingly, AF6 was found in both, maintaining epithelial cell-cell junctions/polarity [75] and negative regulation of RAP1-mediated cell adhesion [76]. 
For PKC $\zeta$, direct interaction with RAS has been shown in vitro and in vivo. The AF6 homolog and RAS-binding protein Canoe is strongly involved in MAPK, int/Wingless (WNT) and Neurogenic locus notch homolog protein (NOTCH) signaling [81]. In Drosophila, the PDZ protein Canoe promotes dorsal closure of the embryo as a RAP1 effector [82] and regulates asymmetric division of neuroblasts [83].

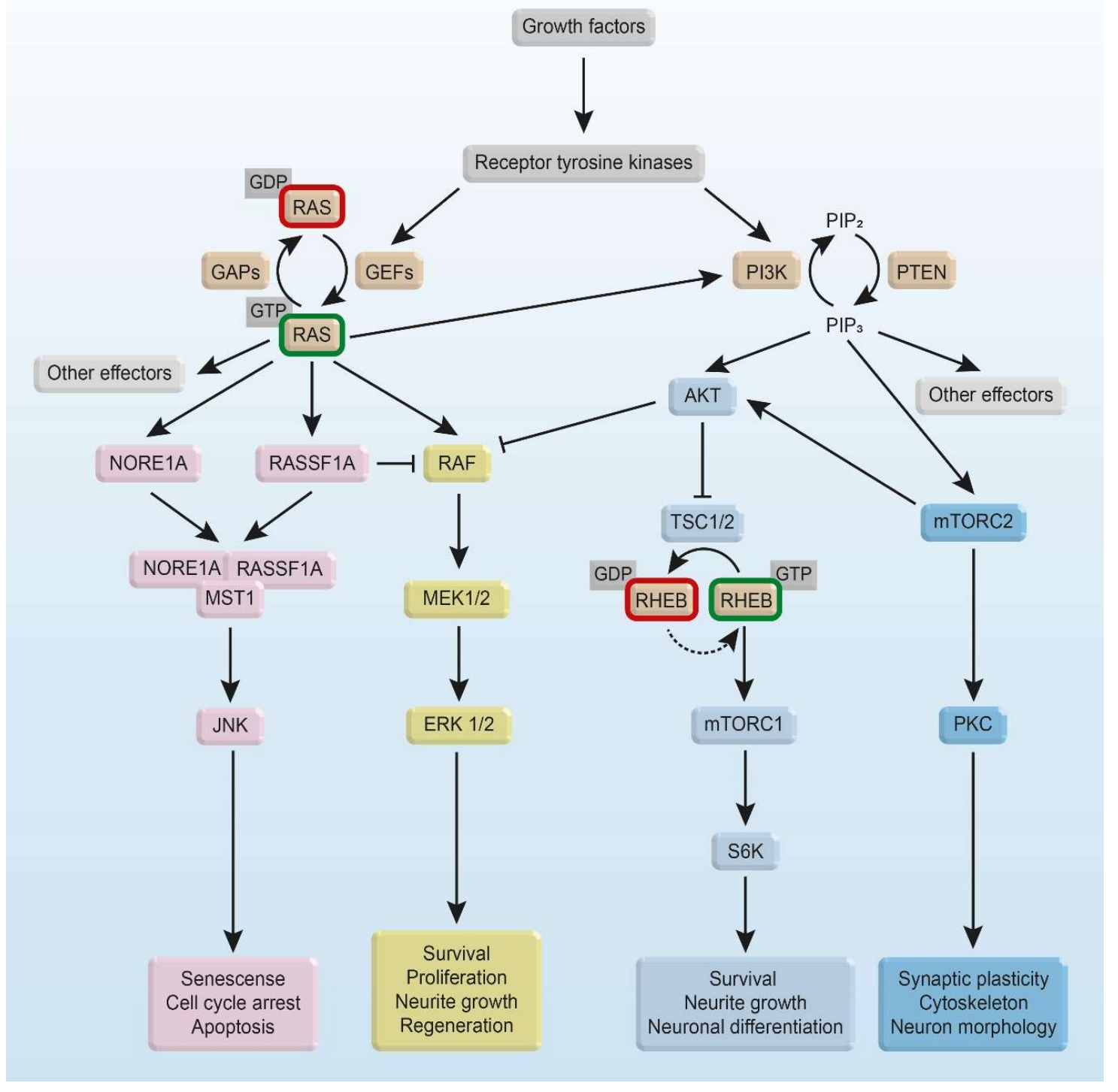

Figure 3. Schematic overview of RAS and PI3K pathway and their interconnection. Binding of growth factors to receptor tyrosine kinases results in activation of RAS and PI3K signaling pathway. Complex-formation of NORE1, RASSF1A, and MST1, together with activated RAS leads to JNK-mediated senescence, cell-cycle arrest or apoptosis [16,84]. RAS-mediated activation of RAF/MEK/ERK signaling plays a role in survival, proliferation, neurite growth, and neuronal regeneration, but the effect differs between various types of neurons [85]. PI3K-mediated phosphorylation of AKT promotes TSC dissociation from lysosomes and RHEB activation. The activation of RHEB by GEF is still under discussion (dashed arrow). Downstream of RHEB, mTORC1 and S6K suppress autophagy and promote survival, neurite growth, and neuronal differentiation [86]. Furthermore, PI3K-mediated mTORC2 activation plays a role in PKC-dependent synaptic plasticity, actin cytoskeleton dynamics, and neuron morphology $[87,88]$. Strong activation of AKT directly inhibits RAF (illustrated by T-bar) and thereby leading to downregulation of ERK1/2 signaling [89]. 


\section{RAS and RHEB Signaling in Survival, Apoptosis, and Neurodegenerative Diseases}

\subsection{RAS Signaling for Survival}

Investigating the possible role of RAS signaling in the physiological function of neurotrophic factors, Borasio et al. showed that the intracellular application of RAS protein was sufficient and necessary to promote survival of embryonic peripheral sensory neurons in the absence of nerve growth factor (NGF) [90]. Various mechanisms have been proposed for the RAS-mediated survival activity. In sympathetic neurons, expression of adenoviral constructs coding for constitutively active RAS enhanced neuronal survival by suppressing p53-mediated cell death signaling pathway [91]. In cerebellar granule cells RAS-MAPK signaling appears to promote cell survival by a dual mechanism. It induces expression of pro-survival genes in a cAMP-responsive element-binding protein (CREB)-dependent manner and diminishes cell death by phosphorylating and thereby inhibiting the pro-apoptotic protein Bcl-2-associated death (BAD) [92]. Activity-dependent neuroprotection of cerebellar granule neurons (CGNs) by $100 \mu \mathrm{M}$ NMDA and $25 \mathrm{mM} \mathrm{KCl} \mathrm{(K25)} \mathrm{is} \mathrm{mediated} \mathrm{by}$ RAS stimulation through the activation of PI3K-AKT and MEK-ERK pathways [93]. $\mathrm{Ca}^{2+}$-induced activation of RAS is regulated by $\mathrm{Ca}^{2+}$-sensitive RAS-GEFs and RAS-GAPs as well as RAS effector proteins [94,95].

Insights about the role of enhanced RAS activity in brain neurons were advanced by studies on transgenic mice (named synRas) expressing constitutively active H-RAS ${ }^{\mathrm{V} 12}$ under the control of a synapsin 1-promoter [96]. Besides hypertrophy of pyramidal neurons in hippocampus and cortex, constitutively active RAS protected motor neurons from degeneration after lesion of the facial nucleus. In addition, survival of tyrosine hydroxylase (TH)-positive neurons of the substantia nigra was enhanced after exposure to dopaminergic neuron-specific toxins [97]. Felderhoff-Mueser et al. showed the resistance of synRas neonates' brain neurons to toxic hyperoxia treatment [98]. Based on these findings it was concluded, that neuronal RAS signaling induces neuroprotective effects and thereby has a beneficial influence on traumatic brain injury and neurodegenerative disorders such as Parkinson's disease.

In addition to RAS, PI3K-AKT signaling regulates the development of the neocortex and neuronal survival [99]. PI3K-AKT signaling provides neuroprotective effects by increased expression of anti-apoptotic factors such as B-cell lymphoma-extra-large (BCL-xL) and B-cell lymphoma 2 (BCL-2) through blocking caspase-induced pro-apoptotic pathways [100,101]. Embryonic sympathetic neurons of Bax KO mice were transfected with either activated or inhibitory mutants of neurotrophin TRK-receptor effectors to study axon growth in absence of NGF or its downstream signaling mediators. While RAS was necessary and sufficient for NGF-stimulated axon growth, RAF and AKT-induced distinct morphologies. Similar to NGF, active RAF1 caused axon lengthening and AKT lead to increased axon branching and caliber [102]. Furthermore, inactivation of BAD and Forkhead (FKHR) of the pro-apoptotic cascade emphasizes the impact on survival [103].

Using pharmacological inhibitors and dominant-inhibitory mutants of AKT, Dudek et al. showed that AKT is a critical regulator of growth factor-induced neuronal survival [104]. In particular, AKT is involved in both transcription-dependent and -independent control of apoptosis prevention. On the one hand, AKT promotes survival by inhibitory phosphorylation of pro-apoptotic proteins such as BIM, BAX, or BAD and by Forkhead box transcription factor phosphorylation as well as by indirectly inhibiting the tumor suppressor activity of p53 in hippocampal neurons. On the other hand, AKT induces the expression of pro-survival genes by the activation of CREB and nuclear factor кB (NF-KB) [105].

Furthermore, activation of neuronal RAS/MAPK in cultures derived from neurospheres of synRas animals resulted in an activating phosphorylation of CREB and inactivating phosphorylation of BAD. Thus, the transgenic activation of RAS in mouse ventral mesencephalic neurons leads to an increased Nuclear receptor-related 1 protein (NURR1) expression resulting in enhanced dopaminergic properties 
and a higher number of dopaminergic neurons. In addition, RAS activation counteracted neurotoxic effects of 6-hydroxydopamine (6-OHDA) in dopaminergic neurons [106].

\subsection{RAS Signaling for Apoptosis}

RAS is not only capable of activating cellular transcription, translation, cell-cycle progression, and survival but also apoptosis suggesting that the physiological outcome of RAS activation depends on the cellular context and cell type [5,16]. Cell death plays an important role during the development of the nervous system and in the diseased brain of the adult organism and which is mediated by various signaling pathways, including RAS [107]. Apoptosis, also referred to as programmed cell death, is characterized by nuclear fragmentation, chromatin condensation, and cell shrinkage by an evolutionary highly conserved cellular mechanism [108]. Previously, several publications already demonstrated a link between RAS activity and apoptosis, e.g., RAS inhibition prevents FAS-mediated apoptosis [109]. Furthermore, glioblastoma cells undergo cell death by hyperstimulation of RAS-triggered macropinocytosis [110]. In the rabbit lens epithelial cell line N/N1003A, $\mathrm{Ca}^{2+}$-induced RAS activation mediates p53-dependent apoptosis via the RAF/MEK/ERK pathway [111]. Several reports describe the crosstalk between the RAS family and proteins of the BCL-2 family in balancing cell death and cell proliferation [112]. Using neurospheres derived from mice with transgenic activation of RAS (synRas mice), neural cells showed an increased AKT activity resulting in phosphorylation of BAD and thereby inhibiting this pro-apoptotic protein of the BCL-2 family [106].

The RASSF protein family consists of ten members in which RASSF1-8 have multiple splicing variants [113-115]. RASSF proteins lack any enzymatic activity and function as scaffolding proteins [116]. Many RASSF proteins contain a N-terminal RA domain for the interaction with RAS [115]. Thereby, the RAS signaling pathway is directly linked to the modulation of apoptosis, autophagy, senescence, inflammation, and DNA repair.

The first identified member of the RASSF family was RASSF5, also known as novel RAS effector 1 (NORE1), is expressed in three isoforms (A-C) resulting from differential promotor usage and alternative splicing. NORE1 selectively binds to RAS in the activated GTP-bounded state (Figure 3) [117] and leads to apoptosis via death receptor-mediated apoptosis [118,119]. The interaction between NORE1 with RAS and mammalian sterile 20-like (MST1/2) kinase is well described. All three isoforms of NORE1 can build a constitutive complex with MST1 in vivo and serum stimulation induces association of NORE1-MST1 with endogenous RAS forming a trimeric complex. In several cell lines, apoptosis is induced by overexpressing constitutively active K-RAS ${ }^{\mathrm{V} 12}$ or by using the effector loop mutant H-RAS ${ }^{\mathrm{V} 12-\mathrm{G} 37}$ resulting in less potent effects, however [120]. Recently, Koturenkiene et al. showed the formation of a stable complex between active H-RAS, NORE1A, and MST1 in vitro without any further factors involved. In addition, they clearly demonstrated that NORE1A has two binding sites: the RBD domain for binding of H-RAS and simultaneously the Salvador-RASSF-Hippo (SARAH) domain for binding of MST1 [121]. Several studies showed that MST kinases are clearly involved in neuronal signaling pathway as well as in the development of diseases in the central nervous system (CNS) [122].

As discussed above, the transgenic expression of activated H-RAS ${ }^{\mathrm{V} 12}$ in postmitotic neurons promoted neuroprotection after various types of brain lesion and in disease models [96]. In contrast, transgenic expression of $\mathrm{H}-\mathrm{RAS}^{\mathrm{V} 12}$ selectively in mature mouse oligodendrocytes resulted in myelin disruption via increased MAPK activity and was associated with nitric oxide production and NOTCH signaling [123]. These different physiological effects in response to enhanced RAS activity (H-RAS ${ }^{\mathrm{V} 12}$ expression) might be explained by the cell type-specific readouts in neurons or oligodendrocytes, respectively.

Recently, Serdar et al. showed that oligodendrocytes are protected from hyperoxia-induced brain injury due to the transgenic increase of neuronal H-RAS ${ }^{\mathrm{V} 12}$ in the immature brain of synRas mice. The results suggest that neuronal activation of RAS may generate secondary protective effects in surrounding oligodendrocytes [124]. These studies may have relevance for investigations towards 
understanding the mechanism of RAS-related genetic diseases. Castello syndrome is a Rasopathy, in which heterozygous activating germ-line mutations in the $H$-RAS gene cause multiple congenital anomalies such as cardiomyopathy, loose skin, coarse face, predisposition to tumors, and mental retardation [125]. In summary, in the brain RAS is involved not only in survival but also in degenerative processes depending on the developmental stage and cell type.

\subsection{Subcellular Localization-Dependent Signaling of RHEB}

RHEB not only influences cellular growth, protein translation, proliferation, and cell cycle but also apoptosis. In absence of e.g., growth factors, the TSC1-TSC2-complex binds to lysosome anchored RHEB-GDP and maintains its GDP-bound state. In presence of growth factors, AKT phosphorylates TSC2, which then dissociates from the TSC1-TSC2-complex and is not able to inhibit RHEB activity anymore $[15,126,127]$. An additional mechanism of regulating RHEB activation results from amino acid-induced direct binding of the RAS-related small GTPase recombinase-activating gene (RAG) to endomembrane systems [128]. This brings mTORC1 into proximity to RHEB, which allows its activation of mTORC1 by GTP-bound RHEB and leads to further downstream signaling [30]. Conversely, removal of amino acids increases the binding affinity of RAG to TSC1-TSC2-complex and its recruitment to the lysosomal membrane, which facilitates the inactivation of RHEB [129]. Taken together, activation of mTORC1 at the lysosomal membrane needs the synergy of amino acid- and growth factor-mediated signals. Both stimuli play a key role in activation, but neither is sufficient to activate mTORC1 alone $[15,86,126,129]$.

Despite the growth factor- and amino acid-mediated activation, $\mathrm{mTORC} 1$ is activated by oxidative stress, starvation stress, and ER stress [130-132]. The redox-sensitive regulation is found due to an increase of the active GTP-bound state of RHEB by cysteine oxidants. These have only minor impact on mTORC1 localization which leads to the conclusion, that this regulation of mTORC1 is independent of RAG [131].

In contrast to oxidative stress, hypoxia-induced stress results in an inhibition of the mTOR pathway. BCL-2/adenovirus E1B $19 \mathrm{kDa}$ interacting protein 3 (BNIP3) is a mitochondrial pro-apoptotic protein member of the BCL-2 superfamily and is activated by hypoxia [133]. Under hypoxic conditions, BNIP3 binds to RHEB resulting in an inhibition of the interaction of RHEB with its downstream effectors as well as a decreased level of RHEB-GTP [134].

\subsection{RHEB-Mediated Enhancement of Apoptosis}

The initial report regarding RHEB showed seizure-induced upregulation of RHEB mRNA in hippocampal neurons [9]. Furthermore, mRNA of RHEB was upregulated upon ultraviolet (UV) irradiation implicating that RHEB could sensitize cells to apoptotic stimuli [135]. This corresponds to the observation that injuries upregulate the expression of RHEB both on mRNA and protein level in the CNS $[136,137]$. Karassek et al. demonstrated that transient overexpression of RHEB followed by toxic stimuli, i.e., application of tunicamycin, TNF $\alpha$ treatment, or UV irradiation led to enhanced apoptosis in a mTORC1-dependent manner in HeLa cells. Similarly, apoptosis was also enhanced by overexpression of RHEB in primary cortical neurons after excitotoxic stimulation with glutamate. This enhancement was prevented by the knockdown of endogenous RHEB. The pro-apoptotic RHEB signaling was mediated by apoptosis signal-regulating kinase-1 (ASK-1) [138] which is activated by ER stress or oxidative stress [139].

Another mechanism of RHEB/mTOR-mediated enhancement of cellular degeneration results from its negative regulation of autophagy [140]. RHEB activation inhibits autophagy leading to cellular damage, which is especially obvious in neurodegenerative phenotypes when insoluble intracellular aggregates accumulate and induce neuronal death [141-143]. Furthermore, permanent activation of RHEB by the cellular loss of TSC1 or TSC2 induces ER stress resulting in unfolded proteins leading finally to apoptosis in tumors and mouse embryonic fibroblasts [144]. Correspondingly, primary hippocampal neurons deficient in TSC2 showed enhanced ER stress-inducing cell death [145]. 
Moreover, as ER stress is coupled to oxidative stress, the cellular reactive oxygen species (ROS)-levels increased in hippocampal neurons [132]. In general, neurons are more susceptible to oxidative stress than cells of other tissues [146].

It is well described that RHEB activates mTOR kinase, which in turn phosphorylates 4EBP1 and S6K and finally stimulates protein synthesis. Conversely, RHEB can also inhibit protein synthesis by activating protein kinase-like ER kinase (PERK), leading to phosphorylation of the initiation factor eIF2 $\alpha$ and thereby inhibiting protein synthesis. This RHEB-PERK pathway is activated under cellular stress, suggesting that cells may respond differently depending on the specific environmental conditions [147].

\subsection{RHEB in Neurodegenerative Disease}

RHEB is involved in neurodegenerative diseases, such as Huntington's disease (HD). In HD, the protein huntingtin (HTT) contains an expanded poly-glutamine (poly-Q) tract. Typical symptoms of HD are impaired motor and cognitive functions. Under healthy conditions, HTT stimulates signaling through mTORC1. In the case of HD, the poly-Q tract potentiates the signaling because a ternary complex of HTT-RHEB-mTOR is formed, leading to enhanced mTORC1 activity [148]. In contrast to these findings, a reduced striatal mTORC1 activity was observed along with a changed metabolic and degenerative phenotype in the brain of HD patients. Furthermore, constitutively active RHEB increased mitochondrial dysfunction and striatal atrophy influenced the cholesterol homeostasis and impaired dopamine signaling in a mouse model of HD [149].

Another example for the involvement of RHEB in neurodegenerative diseases is Alzheimer disease (AD). A hallmark of AD pathology is the generation of amyloid beta $(A \beta)$ from the amyloid precursor protein (APP) by APP-cleaving enzyme 1 ( $\beta$-secretase, BACE1) at the $\beta$-site of APP. RHEB in its GTP-bound state regulates the stability and activity of BACE1. Protein levels of BACE1 and $A \beta$ generation are suppressed upon RHEB overexpression. The interaction of GTP-activated RHEB with BACE1 stimulates its degradation via the proteasomal and lysosomal pathways. These findings correspond to the pathological situation of $\mathrm{AD}$, as a reduced expression level of RHEB leads to an increased expression of BACE1 in brains of AD patients [150].

More details about the role of RHEB regarding degeneration, regeneration, and connectivity can be found in recent review articles by Ehrkamp et al. and Potheraveedu et al., respectively $[16,86]$. Taken together, RHEB is not per se involved in apoptosis but only under certain physiological or pathological cellular states.

\subsection{RAS Signaling and Neurite Growth}

During development of the nervous system, neural cells must navigate through a complex and dense packed environment to establish necessary synaptic contacts in the target region. The first event of neuronal morphogenesis is neurite initiation. Neurites are protrusions that emerge from the cell body and are subclassified in axons and dendrites. Each of these cell protrusions forms a growth cone, which extends to filopodia and lamellae. To sense signal molecules and nutrients, these structures are endowed with adequate receptors. To react to these external stimuli, the motility of the growth cone is ensured by strong cytoskeletal dynamics [151,152]. In hippocampal neurons it is shown, that only one axon, but several dendrites can exist at the same time. If this initial axon is transected, in most cases an existing dendrite converts to an axon. Furthermore, dendrites are inhibited to evolve to an axon, if one neuronal process acquired axonal characteristics [153]. However, multiple axon formation is possible by unregulated growth due to GSK-3 $\beta$ inhibition $[154,155]$.

Neurite initiation can be triggered by the binding of neurotrophic factors to receptor tyrosine kinases (RTKs). Experiments with rat pheochromocytoma cells (PC12) show, that the binding of NGF to TRKA receptor is crucial for RAS activation. This further leads to ERK activation, mediated by the protein kinase RAF and MAPK [156-159]. Clear evidence, that RAS activation is sufficient for neurite outgrowth was provided by experiments in which constitutively active H-RAS ${ }^{\text {V12 }}$ protein was 
microinjected in PC12 cells. In these cells, neurite outgrowth was promoted thus showing a neuron-like morphology, which is comparable to the induction with NGF [160]. The intracellular application of H-RAS ${ }^{V 12}$ protein in dorsal root ganglion (DRG) neurons showed similar effects [90]. These effects are reversible upon microinjection of anti-H-RAS ${ }^{\mathrm{V} 12}$ antibodies [160] and do not occur if truncated H-RAS ${ }^{\text {V12 }}$ is delivered to the cell [90].

Deprivation of embryonic peripheral sensory and sympathetic neurons from neurotrophic supply results in cell death thus compromising the investigation on intracellular signaling mechanisms of neurite growth. To enable neurotrophin-independent neuronal survival, experiments were performed with neurons derived from $\mathrm{Bax}^{-/}$mice. In these neurons, overexpression of dominant-negative RAS or RAF mutants, as well as pharmacological inhibition of MEK, completely blocks axon growth. Conversely, specific activation of either RAS or RAF is sufficient for sensory axon elongation [102]. Downstream of RAS and RAF signaling, the kinases ERK1 and ERK2 play a key role in neurite growth. Overexpression of the constitutively active fusion protein ERK2-MEK1 is sufficient to phosphorylate ETS domain-containing protein ELK-1 (ELK1) in vivo and to induce ELK1- and activator protein 1 (AP-1)-mediated transcription, resulting in neurite outgrowth in PC12 cells [161]. Despite the translocation of activated ERK2 to the nucleus which leads to the activation of transcription factors, a diffused localization in the cytoplasm and a strong localization at the extending neurites can be observed. This observation suggests that ERK2 phosphorylates distinct effectors at the membrane that contribute to neurite formation [161]. Among these, ERK substrates such as the gap junction protein connexin [162,163], cytoskeletal proteins such as microtubule-associated proteins (MAPs) [164,165], TAU [166], and vinexin [167] are discussed.

In addition to RAF, the PI3K-AKT-pathway is activated by RAS but with different effects on neurite morphology [102]. PI3K is shown to be required for axon growth in sympathetic neurons [168]. In sensory neurons, selective activation of PI3K or AKT does not significantly contribute to axon elongation but leads to a doubled diameter of E13 axons [102]. PI3K activation is localized to the growth cone where it inactivates GSK-3 $\beta$. In addition, PI3K downstream target integrin-linked kinase (ILK) supports the inactivation of GSK-3 $\beta$ directly by phosphorylation [169]. Due to the inactivation of GSK3- $\beta$, its downstream target adenomatous-polyposis-coli (APC) is not phosphorylated and can bind to the plus- ends of microtubules in the growth cone which increases microtubule stability [170]. Furthermore, inactivated GSK-3 $\beta$ cannot phosphorylate the collapsin response mediator protein-2 (CRMP-2), which allows axon formation by mediating microtubule assembly [171] and modulating microtubule dynamics [172]. PI3K also activates RAC1 at the plasma membrane which leads to the activation of the WASP-family verprolin homologous protein (WAVE) complex and further to actin polymerization mediated by the ARP2/3 complex [173].

Although there is some knowledge about the mechanisms of neurite growth, in the adult CNS spontaneous regrowth is very limited, if neurons lose their axons due to injury or disease. In contrast to this, neonatal CNS axons are capable to regenerate after being injured $[174,175]$. These observations led to the suggestion to use peripheral nerves as a support to overcome the inhibitory cues preventing long-distance regeneration in the CNS [176,177]. In addition, these experiments raised the question, whether the reactivation of developmental growth mechanisms could empower adult CNS axons to regenerate again [178]. It has been shown that the application of growth factors could rescue neuronal death after axotomy $[179,180]$ which brought again into focus the RAS-ERK and PI3K-AKT pathways [181]. Further pathways that play a role in regeneration will not be discussed in detail but have been excellently elaborated in recent reviews [182,183].

\subsection{TRK Receptor-Mediated RAS/RAF/ERK Pathway}

Animal models overexpressing tropomyosin receptor kinase B (TRKB) in adult layer V motor cortex neurons showed, that upon subcortical aspiration lesions, these neurons successfully regenerated, and their axon grew towards brain-derived neurotrophic factor (BDNF)-secreting subcortical grafts. In contrast, overexpression with a truncated TRKB mutant which is not capable to 
activate the ERK/MEK pathway did not lead to neuronal regeneration [184]. Expression of fibroblast growth factor 2 (FGF-2) in retinal ganglion cells significantly leads to regenerative axon growth after a microcrush lesion of the optic nerve. This effect is also dependent on ERK activation and can substantially be blocked by administration of a specific ERK inhibitor (PD980590) [185]. Despite its anti-apoptotic and neuroprotective effect [186], overexpression of BCL-2-associated athanogene-1 (BAG1) promotes axon regeneration of retinal ganglion cell (RGC) after optic nerve crush. It is shown, that BAG1-overexpression activates RAF-1 and induces translocation from the membrane to the cytoplasm followed by RHO-associated protein kinase 2 (ROCK2) translocation from the membrane to the perinuclear region. However, overexpression of MEK1 is not sufficient for axon regeneration after optic nerve injury, although ERK1/2 is phosphorylated [187].

Recent studies underlined the importance of B-RAF in axon growth and regeneration. Overexpression of conditional active B-RAF in mice was sufficient to rescue nociceptor axon extension in the absence of TRKA signaling. After dorsal root crush injury, overexpression of conditional active B-RAF in DRGs resulted in axons that penetrate the dorsal root entry zone (DREZ) and grew into the spinal cord, whereas wild type DRGs stopped at the DREZ as they respond to its growth-inhibitory signals. Similar results were obtained for RGC axons after optic nerve crush. When RAF downstream effector kinases MEK1 and MEK2 are knocked out, regenerative axon growth induced by constitutive active B-RAF is substantially inhibited [188]. By silencing suppressors of mTOR pathway such as PTEN, TSC1, and TSC2, axon regeneration after injury is likewise stimulated in CNS and peripheral nervous system (PNS) neurons [189-192]. Furthermore, regeneration is successfully blocked by administration of mTOR inhibitor rapamycin, which implicates an important role of the mTOR pathway [189]. The combination of overexpression of B-RAF and silencing of PTEN leads to enhanced regenerative axon growth by a synergistic effect of B-RAF and PI3K signaling [188].

\subsection{Other Intracellular Mechanisms Signaling for Regeneration}

Besides B-RAF and PI3K signaling, other genetic and epigenetic changes in injured neurons are discussed to play an important role in regeneration. RHO GTPases such as Ras homolog gene family, member A (RHOA), CDC42, and RAC1 play a crucial role in neurite growth by regulation of the actin polymerization [193]. RHOA inhibits neurite growth in response to neurite outgrowth inhibitor (NOGO), myelin-associated glycoprotein (MAG), whereas administration of the RHOA inhibitor C3 improved neurite outgrowth. Furthermore, inhibition of RHOA downstream effector ROCK showed comparable results. In contrast, CDC42 and RAC1 are positive regulators of axon growth and induce lamellipodia and filopodia formation [193,194]. Damage of the axonal membrane results in an increased influx of calcium ions [195] and higher levels of the second messenger cAMP [196]. The increased cAMP levels then activate pro-regenerative proteins such as CREB1 [197] and dual leucine zipper-bearing kinase (DLK) [198]. Poly(ADP-ribose) polymerase 1 (PARP1) is activated when neurons are exposed to growth-inhibiting molecules such as MAG, myelin protein NOGO and myelin membrane-associated chondroitin sulfate proteoglycans (CSPGs) [199]. Activation of PARP1 leads to increased poly(ADP-ribose) levels, resulting in limited axonal growth [200], but pharmacological inhibition or genetic deletion of PARP1 is not sufficient to promote axonal growth alone [201]. In addition, axonal regeneration can be enhanced by knocking out the ribonucleic acid (RNA) processing enzyme 3'-terminal phosphate cyclases A and B (RTCA and RTCB), which are important for RNA repair and stress-induced mRNA splicing [202,203]. Analysis of transcriptional changes in different neuronal cell lines revealed that transcription factors such as p53, c-Jun, ATF3, CREB, STAT3, NFATs, NF-KB, SOX11, SNON, and the Krüppel-like family of transcription factors (KLF) family are involved in axon growth and axon regeneration. In particular, NF- $\mathrm{kB}$ has been shown to be involved in regrowth of the genetically damaged hippocampus [204]. These regenerative activities are highly dependent on the cellular or genetic context. Upregulation of transcription factors that are promoting axon growth only occurs in early development or in cells that are capable of regeneration. Furthermore, anti-axon growth factors dominate when both, growth enhancing and 
growth suppressing transcription factors are upregulated [205]. Epigenetic changes, such as histone or DNA modifications in the context of developmental axon growth is highly investigated, but the role in regeneration is not clearly understood, yet [182].

As axon growth is controlled by an orchestra of enhancing and suppressing stimuli, more recent studies try to target a combination of different pathways. mTOR activation by expression of constitutively active RHEB was shown to enhance neuronal survival and axon growth of substantia nigra dopaminergic neurons after a neurotoxin-induced lesion [206]. After spinal cord injury, the expression of constitutively active RHEB is not sufficient for axonal regeneration. In combination with CSPG digestion, the number of propriospinal axons that are capable of reinnervating distal spinal cord significantly increased, and sprouting was enhanced $[207,208]$.

\section{Optogenetics}

Optogenetics combines genetic and optical methods to control biological processes in living systems, ranging from single cells over tissues to organisms [209]. With optogenetic tools, the vision to understand cellular functions, dynamics and decision-making processes extended considerably. In addition, intensity and timing of signals depending on optogenetic assays allow dissecting molecular networks and quantitative understanding of information flow as well as its functional mapping in a native cellular context.

\subsection{Light-Directed Protein-Protein Interaction Devices}

Photosensitive switches are proteins that have been modified to regulate a wide variety of signaling pathways in living cells through conformation changes in response to light. Mainly, the plant proteins cryptochrome [210,211], light-oxygen-voltage (LOV) [212] and phytochromes [213,214], as well as the fluorescent protein DRONPA [215], have been applied as reversible optogenetic systems to control signaling pathways [216]. Cryptochrome 2 (CRY2) is a protein isolated from Arabidopsis thaliana which uses a ubiquitously expressed endogenous flavin as a chromophore. Upon exposure to blue light (405-488 nm), CRY2 homooligomerizes [217] and binds to its interaction partner cryptochrome-interacting basic helix-loop-helix 1 (CIB1) within seconds. CRY2 resets in the dark to its initial state within 5 min after activation [211]. The LOV domains from different organisms are all sensitive to blue light (440-473 nm) using flavin as their chromophore. In the dark, the flavin-binding domain binds to its carboxy-terminal helical extension $(\mathrm{J} \alpha)$. Light exposure results in a covalent binding of the flavin chromophore and $\mathrm{Cys}^{450}$ leading to the release of its autoinhibitory conformation [218]. Alternatively, the LOV domain fused to the DNA-binding domain of Gal4 homodimerizes and binds to DNA upon blue light activation to regulate gene expression [219]. In addition, the LOV2 domain has been used to cage a peptide epitope and thereby blocking the binding of its interaction partner PDZ. This opens the possibility to regulate a vast number of PDZ-dependent cellular functions [220]. Furthermore, Guntas et al. embedded the SSRA peptide in the C-terminal helix of the LOV2 domain from Avena sativa to create a system being highly efficient in changing binding affinity upon light stimulation. This avoids cross-reactions with other molecules in the cell and is therefore used in a variety of organisms for protein recruitment. In the dark, LOV2 domain prevents the SSRA peptide from binding to its partner SSPB, while upon blue light stimulation the C-terminal helix undocks and thus allows SSPB binding. By computational protein design, phage display, and high-throughput binding assays, the affinity for SSPB has been increased by over 50 -fold to generate an improved light-inducible dimer (iLID) [221,222].

For gaining deeper insights, CRY2/CIB1, iLID/SSPB, and LOVpep/PDZb were compared. In vivo colocalization and functional assays showed dramatic differences in the dark and lit state binding affinities correlating with changes in transcription control and GTPase signaling [223].

Phytochrome B (PHYB) is a protein that is activated by red light at $650 \mathrm{~nm}$ and inactivated by infrared light at $750 \mathrm{~nm}$ within seconds [224]. In cells expressing chromophore-free apo-PHYB protein, a light-sensitive system is generated as soon as phycocyanobilin (PCB) is bound. This chromophore is 
present in photosynthetic organisms, while in non-photosynthetic organisms, PCB must be synthesized by recombinant enzymes or directly delivered to cells $[225,226]$. Upon red light illumination, the PHYB-PCB complex alters conformation and binds to the phytochromes interacting factor (PIF) thus activating the desired signaling pathway [213].

Another mechanism is described by using DRONPA which is a photoactivatable fluorescence protein whose quaternary structure is changed by light activation independent of small-molecule chromophores. Upon photoactivation at 390 nm, DRONPA switches from a monomeric "dark state" to a dimer in the "fluorescent state" thereby inhibiting the function of fused protein of interest. Illuminating with light at a wavelength of $490 \mathrm{~nm}$, the conformational change can be reversed and DRONPA is converted back to a monomer. Thus, observing DRONPA fluorescence enables to track the extent of protein inhibition $[215,216]$.

\subsection{Light-Mediated Activation of RAS/RAF/ERK}

As discussed above MAPK/ERK-mediated signaling plays a key role in cell differentiation, proliferation, apoptosis as well as survival [227]. To activate MAPK-signaling pathways by light has been first shown in yeast by recruiting the scaffold protein STE5 to the membrane and thereby activating MAPK. Upon blue light stimulation, MAPK signaling was activated by binding of STE5 fused to a PDZ domain to a membrane-anchored LOV-epitope fusion protein [220]. Meanwhile, the iLID system has been combined with the two RHO GTPase family members RAC and CDC42 to induce lamellipodia and directed migration on a fibronectin substrate [228].

Based on a PHYB-PIF6 system, MAPK-signaling cascade was induced by light in mammalian cells. The catalytic domain of RAS-GEF SOS (SOScat) was fused to PIF6 whereas PHYB was anchored to the membrane. Upon red light-induced PHYB-PIF6 binding and SOScat recruitment to the membrane, the RAS/MAPK (ERK) pathway was activated by transient (20 $\mathrm{min}$ ) or sustained (120 $\mathrm{min})$ illumination. Response was measured by a high-throughput proteomic method monitoring total- and phospho-protein levels. A group of proteins was defined that were phosphorylated or upregulated after both transient and sustained RAS activation such as members of the PLC/PKC signaling pathway and P90RSK. In addition, other proteins exclusively reacted to the sustained RAS activation such as members of the mTOR pathway, STAT3, and zinc finger protein SNAI1 (SNAIL). Taken together, these methods combine distinct temporal patterns of RAS activation with proteome profiling [229].

RAF/MEK/ERK light-mediated activation has also been shown by using the CIB1-CRY2 system. CRY2 was fused to RAF1 and CIB1 anchored to the plasma membrane. Upon blue light stimulation, RAF1 membrane recruitment leads to an activation of RAF1 and its downstream targets. In the absence of NGF, RAF1 signaling activation induced neurite outgrowth in PC12 cells. Astonishingly, permanent ERK activation was not required, while periodic on/off light stimulation was sufficient to support maximum neurite outgrowth, showing a 45 min unrevised threshold for the light-off phase [230]. Using the CRY2-C-RAF/CIB1 system as light-switchable ERK activation system, Aoki et al. showed the propagation of ERK activity pulses to the neighboring cells [231] and induction of collective cell migration [232]. In a different study, the heterodimerization of CRY2-RAF1 and CIB1-RAF1 blocked RAF-RAF interaction by steric effects thus preventing ERK activation [233]. Recently, Dine et al. engineered FGFR1-OptoDroplets to convert transient local inputs to persistent local clustering and cytoskeletal contraction, thus harnessing spatial memory in RTK signaling [234].

Goglia et al. demonstrated the control of RAS activity by "Opto-SOS", using the PHY-PIF system. Functional control of "Opto-SOS" expression was monitored with a live-cell reporter imaging ERK responses. This revealed a highly quantitative input-to-output map of the signaling pathway [235]. "Opto-RAF", is a light-mediated tool to activate RAF and to mimic RAS-triggered dimerization, which allows studying the effect on RAF signaling induced by B-RAF and C-RAF hetero- and homodimer formation. The B-RAF and C-RAF protein kinase inhibitors vemurafenib and dabrafenib suppress oncogenic B-RAF ${ }^{\mathrm{E} 600}$ kinase activity. Opto-RAF activity was enhanced by dabrafenib at a low dose and inhibited at a high dose. Thus, vemurafenib has been identified as a paradoxical activator of B-RAF 
and C-RAF homo- and heterodimers [236]. In PC12 cells, RAF kinase induced cell differentiation by light-controlled RAF/MEK/ERK signaling using the CRY2 protein together with the N-terminal domain of cryptochrome-interacting basic-helix-loop-helix (CIBN). Applied to Xenopus embryos, RAF kinase could be reversibly activated at any desired developmental stage in specific cell lineages dependent on light stimulation [237].

Taking together, the activation of the RAS/RAF/MAPK pathway using light-switchable protein-protein interaction devices is a versatile tool to control cell differentiation, migration, and neurite outgrowth in a spatiotemporal manner.

\subsection{Light-Mediated Activation of PI3-Kinase}

Regulation of PI3K is involved in cellular functions such as survival, growth, migration, and progression [238]. Phosphorylation of PIP3 by PI3K has been coupled with light-inducible systems thereby activating downstream pathways such as protein kinase C (PKC), RAC, and AKT. Activation of the PI3K-PIP3 signaling pathway by light has been shown by the PIF6-PHYB membrane recruitment system [239] as well as the CIB1-CRY2 protein aggregation [240]. In addition, the CIB1-CRY2 protein system has been used to regulate the phosphoinositide metabolism, leading to local activation of the 5-Ptase phosphatase and by this to a loss of membrane ruffling, whereas recruiting PI3-kinase to the membrane produced PIP3 [241].

\subsection{Combined Activation of RAS- and PI3K-Pathways}

Kim et al. controlled the activity of the fibroblast growth factor receptor (FGFR) and its three downstream signaling pathways RAS/RAF/ERK, PI3-kinase, and PLC by illumination with blue light on a second-based time-scale through CRY2 oligomerization. CRY2 was inserted between the cytosolic catalytic domain of FGFR and a membrane-targeting sequence. Upon light stimulation, CRY2 oligomerization caused autoactivation of the receptor and subsequently activation of all three downstream signaling pathways [242]. The chimeric receptor Opto-mFGFR1 was generated by fusing the LOV domain of Aureochrome 1 from Vaucheria frigida to the intracellular catalytic domain of murine FGFR1 and thus showing MAPK/ERK pathway activation upon blue light-stimulated dimerization of LOV domains [243].

Ono et al. studied the photoactivated expression of differentiation-associated markers in the channelrhodopsin-2 expressing OS3 (OS3ChR2) cells that are clonal bipotential glial progenitor cells. Channelrhodopsin-2 is a blue light-sensitive cation channel for the control of ion influx. Upon blue light activation, increased $\mathrm{Na}^{+}$- and $\mathrm{Ca}^{2+}$-ion concentrations led to ERK1/2 signaling which resulted in cell growth and survival [244]. Dependent on the light intensity, Opto-CNK1 stimulated RAF/MEK/ERK or AKT signaling in Michigan Cancer Foundation 7 (MCF7, human breast adenocarcinoma cell line) cells. At low light intensity Opto-CNK1 induced differentiation by stimulating ERK activity, whereas triggering AKT signaling stimulated cell proliferation at higher light intensity [245].

\subsection{Activating the RHO Family of Proteins}

Optogenetics has also been applied to other related protein classes such as RHO GTPases including its members RAC1, CDC42, and RHOA to modify and regulate cellular functions such as cell motility, organelle development, and actin dynamics [227]. RAC1 has been fused to the LOV domain of phototropin and activated by unwinding the helix linking LOV as a photo-cage system. Using $458 \mathrm{~nm}$ or $473 \mathrm{~nm}$ light, RAC1 could be repeatedly and reversibly photoactivated and generated localized cell protrusions and ruffling. By this, cell motility and the direction of movement was controlled [218]. Moreover, RAC1 was fused to flavin-binding, kelch repeat, f box 1 (FKF1) that contains a LOV domain and a light-detecting flavin mononucleotide (FMN). Blue light-induced activation of FKF1 to plant specific nuclear protein GIGANTEA (GI) resulted in translocation to the membrane and increased lamellipodia formation [246]. Levskaya et al. spatiotemporally activated RHO GTPases by light-controlled membrane recruitment of GEFs, e.g., Intersectin (ITSN), TIAM, 
and TIM. GEFs were linked to PIF and PHYB anchored in the plasma membrane. Light-induced membrane recruitment and protein interaction using various optogenetic systems promoted activation of Intersectin and TIAM leading to the generation of lamellipodia in NIH3T3 cells. Recruiting TIAM Dbl-homology domain (DH) / pleckstrin-homology domain $(\mathrm{PH})$ domains to the plasma membrane using different photoactivatable switches led to protrusions of varying size. In particular, in NIH3T3 cells TIAM allowed local induction and protrusion of lamellipodia [223,224]. Zhou et al. linked the CDC42-GEF Intersectin to the DRONPA system enabling membrane recruitment as well as photo-caging of cellular signaling mediators and enzymes. Introducing a Lys ${ }^{145}$ to $\mathrm{Asn}^{145}$ mutation into DRONPA, the homotetrameric complex monomerized upon blue light illumination, which was reversed by violet light. Tandem fusions of the monomeric DRONPAK form and of the tetrameric mutant DRONPAN allowed the reversible dissociation of intramolecular dimers upon blue light stimulation. This photo-uncaging of ITSN caused lengthening of pre-existing filopodia [215,247].

Due to the restricted light penetration into deep brain regions, patient-directed brain regeneration therapies using optogenetic tools are limited. Interestingly, in a recent study by Chen et al., optogenetics has been combined with nanoparticles (UCNPs) absorbing and upconverting the tissue-penetrating near-infrared (NIR) light into visible light to enable remote-controlled optical neuron therapy in the mouse brain. UCNPs stimulate deep brain neurons upon transcranial NIR light illumination evoking dopamine release from genetically modified neurons in the tegmental area [248].

\section{Magnetogenetics}

Remote control of cellular functions in a spatiotemporal manner constitutes an important challenge in fundamental and biomedical research. Recently, physical and chemical techniques have been combined to address genetic and pharmacological issues leading to new approaches in cell behavior control and, consequently, to regenerative medicine applications. Several studies demonstrated the control of cell-lineage differentiation [249], gene expression [250,251], intracellular organelle transport, and positioning [252] as well as directed migration and motility [218,253,254]. New efforts emerged by developing approaches to remotely control biological functions based on magnetic stimulation [255].

Mainly, three research areas arose to investigate the effect of magnetic fields on cellular response. First, there is the research on organisms that can navigate by detecting magnetic fields, referred to as "magnetosensation" $[256,257]$. Second, investigating the influence of strong magnetic fields on biological systems and their processes have been studied to show the response of biopolymers to external magnetic stimulation. Finally, besides their conventional use as drug-delivery systems [258-262] or imaging contrast agents [263,264], functionalized magnetic nanoparticles (MNPs) have been applied to remote-control cellular function and signaling pathways as well as biological events. In particular, this technique combines beneficial effects of deep and non-invasively penetration of magnetic fields into tissues, organisms, and cultured cells with precise modulation of cellular events. We focus in this part on recent progress and applications of magnetic nanoparticles as a promising approach in fundamental and biomedical research, termed as "magnetogenetics" [255].

\subsection{Functionalized Magnetic Nanoparticles in Regenerative Medicine}

Approaches using MNPs to activate or transmit cellular signaling by stretching, twisting, or bending the plasma membrane gained significant influence in recent years. Application of MNPs was expanded to manipulate biological processes and cellular behavior towards tissue engineering and regenerative medicine [265]. MNPs allow precise control with millisecond and submicrometric resolution in single protein assays [266]. Seo et al. used mono-functionalized magnetic zinc-doped ferrite nanoparticles with dielectric silica layer and plasmonic gold shell to force a response of NOTCH receptor and VE-cadherin signaling at the surface of human bone osteosarcoma epithelial (U2OS) cells [250]. Furthermore, magneto-mechanical stimulation with MNPs allows direct gating of ion channels by stretching or deflection. With cube-shaped MNPs bound to stereocilia bundles, 
Lee et al. achieved ultrafast mechanical control of deflection-relaxation dynamics in inner ear hair cells [267]. By fusing genetically encoded ferritin nanoparticles to the transient receptor potential cation channel subfamily $\mathrm{V}$ member 4 (TRPV4), action potentials in neurons were triggered by $\mathrm{Ca}^{2+}$-transients upon applying a static magnetic gradient. Moreover, reward behavior in mice and tactile behavior in zebrafish were affected [268]. Anti-Frizzled functionalized MNPs were used to investigate mechano-stimulation of the WNT pathway activation in human mesenchymal stem cells (hMSC). Remote control of anti-Frizzled-MNPs by an oscillating magnetic bioreactor shows an activation of the WNT/ $\beta$-catenin pathway by a TCF/LEF luciferase reporter assay and demonstrating nuclear localization of $\beta$-catenin [269].

Tseng et al. established a technique for massively parallel mechanical modulation of single-cell behavior by growing magnetic nanoparticle-loaded HeLa cells on defined micro-magnetic patterns. After magnetic manipulation and accumulation of nanoparticles, a highly coordinated response was observed leading to p21-activated kinase (PAK)-dependent filopodia stimulation and oriented cell division [270].

\subsection{Magneto-Thermal Approaches}

Besides magneto-mechanical stimulation, MNPs are used for magneto-thermal approaches to convert field stimulation into heat by placing suitable MNPs in a radio-frequency magnetic field [271]. The commonly used transient receptor potential (TRP) plasma membrane ion channels respond to cold $\left(8-28{ }^{\circ} \mathrm{C}\right.$, i.e., TRPA1 and TRPM8) [272,273] or higher $\left(41-43{ }^{\circ} \mathrm{C}\right.$, i.e., TRPV1, TRPV3, and TRPV4) temperatures [274]. Magneto-thermal stimulus allowed control of $\mathrm{Ca}^{2+}$-influx by TRPV1 gating in HEK293 cells or lead to triggering of action potentials in hippocampal neuronal cells $[275,276]$. Huang et al. first used heating of MNPs in C. elegans near sensory neurons to cause thermal avoidance. Gating of the TRPV1 channel was achieved by fusing them to iron oxide MNPs using biotin-streptavidin interactions and targeting a high concentration of the complexes to the cellular membrane which reduced side effects and increased the heating efficiency of ion channels [275]. Chen et al. showed neuronal excitation in mice by activation of TRPV1 in ventral tegmental brain regions through high concentrations of freely diffusing MNPs in the cytoplasm [276]. Ferritin and synthetic magnetic nanoparticle enable further control of insulin expression and, consequently, blood glucose level in mice $[251,277]$. Controlling neuronal activity by the ferritin-TRPV1 system in hypothalamic glucose-sensing neurons in mice allowed regulating insulin levels and metabolism [278].

\subsection{Magnetic Control of Receptor Clustering}

Finally, MNPs can control cellular functions and biological processes in the cell based on their concentration and spatial distribution. Initially, MNPs bound to membrane receptors triggered their signaling pathways by inducing oligomerization in the plasma membrane upon the magnetic stimulus. Mannix et al. bound MNPs coated with monovalent ligands to transmembrane receptors and accumulated them in the plane of the membrane by bead-bead attraction. By this, clustered FceRI-dinitrophenyl receptor-ligand complexes initiated local inflammatory response and increase of cytosolic calcium [279]. Inducing dimerization of EGF-receptor using biotin-streptavidin coupled EGF-antibodies to MNPs activated the corresponding downstream pathway [280]. By binding iron oxide MNPs to the death receptor 4 (DR4), a magnetic switch was generated, which promotes apoptosis signaling upon magnetic stimulation in vitro. Moreover, the magnetic switch allowed the remote control on a micrometer-scale leading to morphological changes of a zebrafish tail [281].

\subsection{Magnetic Activation of Intracellular Signaling}

Even more challenging is the intracellular control of cellular processes and signaling due to nanoparticle delivery into the cytoplasm without endosomal recycling and surface passivation to guarantee colloidal stability inside the cytoplasmic environment. The functionalization of MNPs with proteins advancing to intracellular nanoactuators that activate signaling pathways by interaction with 
their effectors allow manipulating complex signaling cascades on a subcellular level. In response to an external magnetic field, the nanoactuators can be localized and accumulated at any desired location in the cell [282]. Particularly, biofunctionalized MNPs induced and maintained protein gradients inside living cells with high spatial and temporal resolution [283]. Moreover, superparamagnetic iron oxide nanoparticles (SPIONs) can affect signal transduction pathways depending on their surface coatings. Small negatively charged SPIONs mimic physiological growth factors through ERK and AKT activation by promoting proliferation of RAS-transformed breast epithelial cells with the same efficiency as EGF signaling [284].

Accumulating the RAC1-GEF TIAM coupled to $500 \mathrm{~nm}$ MNPs at the plasma membrane by a magnetic tip lead to cell protrusion and actin cytoskeleton remodeling [285], whereas concentration-dependent RAN-GTP-coupled MNPs initiated faster growth in droplets of Xenopus eggs extract by RAN/RCC1 signaling [286].

\section{Outlook and Perspectives: The Dawn of Magneto Protein Therapy in Brain?}

Axonal regeneration in the adult diseased mammalian brain is required to bridge the interrupted connectivity between the neuronal cell body and the distally innervated target region. Endogenous guidance mechanisms permitting axonal regrowth over large distances are usually not sufficient for functional recovery. Activation of RAS and RHEB GTPase signaling pathways have been shown to support regeneration in various model systems using intracellular applied proteins or transgenic expression in cells or animal models. Global neuronal activation of RAS GTPases protects neurons from degeneration and promote sprouting even into growth-inhibitory regions of the brain [86,289]. However, to recover the correct and functional brain connectivity, a non-invasive method is lacking for achieving directed axonal growth into the target region over long distances.

Optogenetic approaches allowing focal activation of fiber growth by light led to new mechanistic insights in cultured neuronal cells and in animals. Although penetration of light into the brain is limited, upconverting nanoparticles that absorb tissue-penetrating NIR light and emit wavelength-specific visible light were recently used to stimulate dopamine release of genetically tagged neurons even in deep brain regions [248].

Promising magnetogenetic approaches have been achieved to mimic activation of receptors such as WNT, NOTCH, and EGF demonstrating their potential in regenerative medicine. Unfortunately, the above-mentioned advances do not allow to resolve the basic requirement for remote control of directed fiber growth for circuit recovery in the diseased brain.

In neurodegenerative diseases, lost neurons can be replaced by transplantation. Experiments show that human induced pluripotent stem cell (iPSC)-derived dopaminergic progenitor cells survived and functioned as midbrain dopaminergic neurons in a primate model of Parkinson's disease (Macaca fascicularis) [290]. Histological studies demonstrated that the dopaminergic neurons transplanted into the striatal target regions extended dense neurites. Accordingly, there was an increase in spontaneous movement after toxic treatment with 1-Methyl-4-phenyl-1,2,3,6-tetrahydropyridin (MPTP). Based on these advancements, human trials using stem cell-derived dopamine neurons have been initiated, recently [291].

Encouraged by these achievements, future efforts should be made to transplant dopamine precursors directly into the substantia nigra where the neuronal loss occurs in Parkinson's disease. As a prerequisite, guided axonal growth must be achieved in transplanted neuronal axons from the substantia nigra to distally located and denervated striatal target regions. A novel approach is envisaged by loading precursor neurons with protein-functionalized magnetic nanoparticles before transplantation. These nanoparticles are thought to activate suitable GTPases from inside the neuronal membrane and guide them towards the desired target by applying external magnets. This concept is currently part of the EU-project MAGNEURON (Horizon 2020, FET Open, grant agreement No. 686841; Figure 4). 


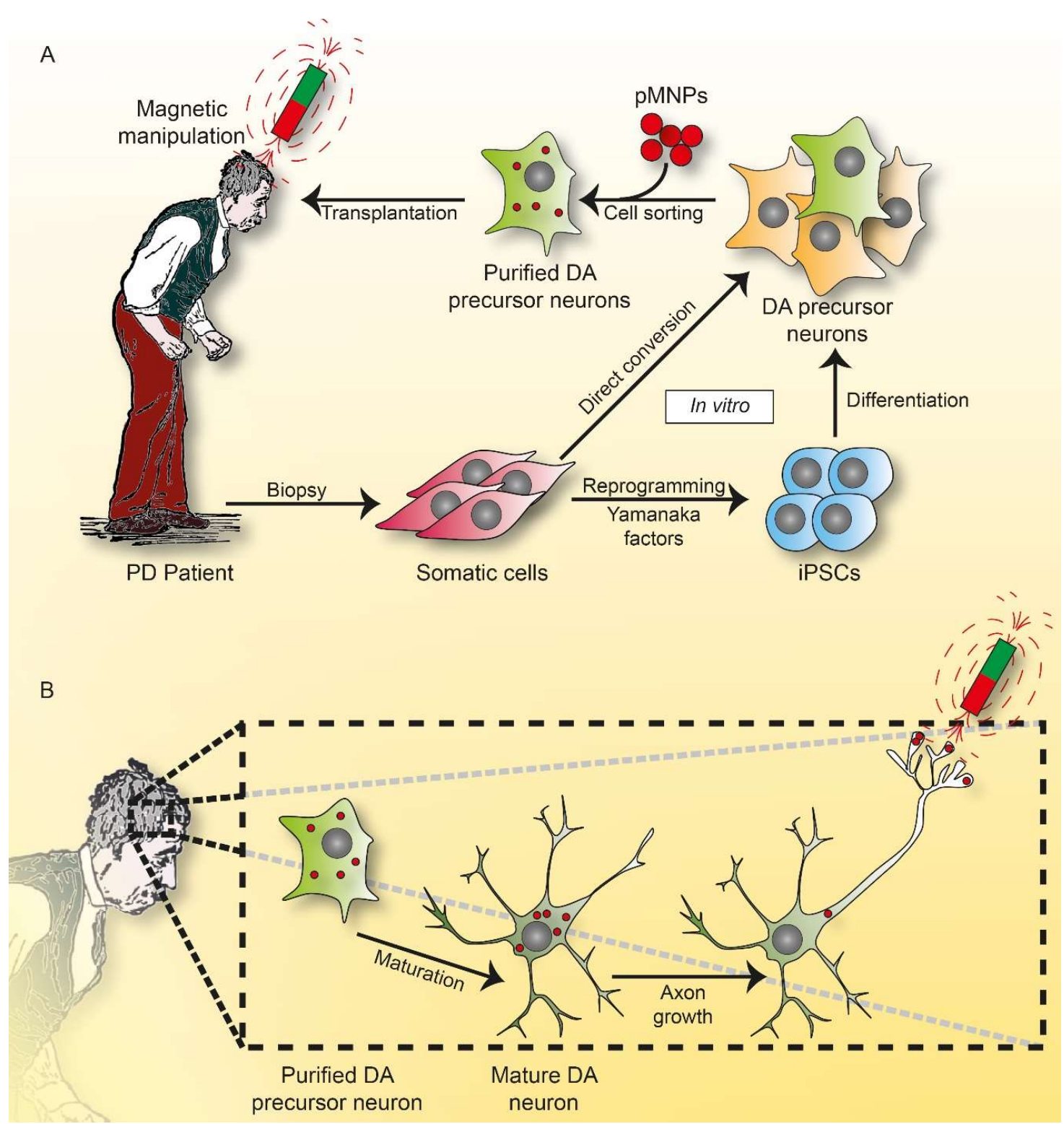

Figure 4. Concept of Magneto Protein Therapy. (A) Somatic cells obtained from Parkinson's patient by biopsy are reprogrammed [287] or directly converted [288] to dopaminergic (DA) precursor neurons in vitro. After cell sorting and loading with protein-functionalized magnetic nanoparticles (pMNPs), these cells are grafted to the striatal target regions or substantia nigra, where neurons degenerate. (B) In the patient's brain, the grafted DA precursor cells convert into mature DA neurons. By the application of an external magnetic field, pMNPs are driven towards the inner membrane of the growing axon thereby activating small GTPases allowing spatially controlled fiber growth.

In contrast to most magnetogenetic experiments described in this review, this above-mentioned concept avoids genetic manipulation in patients. Protein therapy is currently emerging in clinical applications, e.g., by using cell penetrating peptides [292]. Even in cellular models of Parkinson's disease, intracellular protein delivery has been shown to protect toxin-induced neuronal cell death [293]. Here, we propose the application of protein-functionalized MNPs as a novel tool to control intracellular signaling for neuronal regeneration. We call this approach "Magneto Protein Therapy", abbreviated MPT. Ideally, Magneto Protein Therapy, magnetogenetic and optogenetic tools will help to resolve the major problem towards enhancing functional recovery of the lost brain connectivity in neurodegenerative disease. 
Author Contributions: H.S. and F.R. prepared the graphical abstract. H.S. prepared Figures 1 and 2 and wrote the parts: introduction on RAS, neuronal survival, optogenetics and magnetogenetics. F.R. prepared Figure 3 and 4 and wrote the parts: introduction on RHEB, neurite growth and neuronal regeneration. M.C. contributed to the proofreading of the parts: optogenetics and magnetogenetics. S.N. wrote the part: apoptosis of neurons and glial cells. R.H. designed and supervised the manuscript and wrote the parts: abstract and outlook. All authors approved the final version of the manuscript.

Funding: This research was funded by European Union's Horizon 2020 research and innovation program grant agreement No. 686841 (MAGNEURON). We acknowledge support by the DFG Open Access Publication Funds of the Ruhr-Universität Bochum.

Acknowledgments: We are thankful to all our colleagues and collaborators of the MAGNEURON consortium: Maxime Dahan (sadly deceased), Christine Ménager (CNRS, Paris, France), Jacob Piehler (University of Osnabrück, Osnabrück, Germany), Alicia El Haj (University of Birmingham, Birmingham, UK), Monte Gates (Keele University, Keele, UK), and Pierre Joly (Management; Efficient Innovation, Paris, France). We thank Christian Herrmann (Ruhr-Universität Bochum, Bochum, Germany) for critical reading.

Conflicts of Interest: The authors declare no conflict of interest.

\section{Abbreviations}

\begin{tabular}{|c|c|}
\hline 4E-BP1 & Eukaryotic translation initiation factor $4 \mathrm{E}$ (EIF4E)-binding protein \\
\hline 6-OHDA & 6-hydroxydopamine \\
\hline $\mathrm{AD}$ & Alzheimer disease \\
\hline AF6 & Afadin 6 \\
\hline AKT & Protein kinase B \\
\hline AP-1 & Activator protein 1 \\
\hline $\mathrm{APC}$ & Adenomatous-polyposis-coli \\
\hline $\mathrm{APP}$ & Amyloid precursor protein \\
\hline $\mathrm{ARF}$ & ADP ribosylation factor \\
\hline ASK-1 & Apoptosis signal-regulating kinase- 1 \\
\hline ATG13 & Autophagy-related gene 13 \\
\hline$A \beta$ & Amyloid beta \\
\hline BAD & Bcl-2-associated death \\
\hline BAG1 & BCL-2-associated athanogene-1 \\
\hline BAX & Bcl-2-associated $\mathrm{X}$ protein \\
\hline BCL-2 & B-cell lymphoma 2 \\
\hline BCL-xL & B-cell lymphoma-extra large \\
\hline BDNF & Brain-derived neurotrophic factor \\
\hline BIM & Bcl-2-like protein 11 \\
\hline BNIP3 & BCL-2/adenovirus E1B $19 \mathrm{kDa}$ interacting protein 3 \\
\hline CA & Conserved area \\
\hline CAAX & $\mathrm{C}=\mathrm{Cys}, \mathrm{A}=$ aliphatic and $\mathrm{X}=$ any amino acid \\
\hline $\mathrm{CDC}$ & Cell division cycle \\
\hline CDC25 & Cell division cycle 25 \\
\hline CGN & Cerebellar granule neuron \\
\hline CIB1 & Cryptochrome-interacting basic helix-loop-helix 1 \\
\hline CIBN & Cryptochrome-interacting basic-helix-loop-helix, N-terminal domain \\
\hline CK2 & Casein kinase 2 \\
\hline CNK1 & Connector enhancer of kinase suppressor of RAS 1 \\
\hline CNS & Central nervous system \\
\hline CREB & cAMP response element-binding protein \\
\hline CRMP-2 & Collapsin response mediator protein-2 \\
\hline CRY2 & Cryptochrome 2 \\
\hline CSPG & Chondroitin sulfate proteoglycan \\
\hline DCC & Deleted in colorectal cancer \\
\hline DEPTOR & DEP domain-containing mTOR-interacting protein \\
\hline $\mathrm{DH}$ & Dbl-homology domain \\
\hline DLK & Dual leucine zipper-bearing kinase \\
\hline DR4 & Death receptor 4 \\
\hline
\end{tabular}




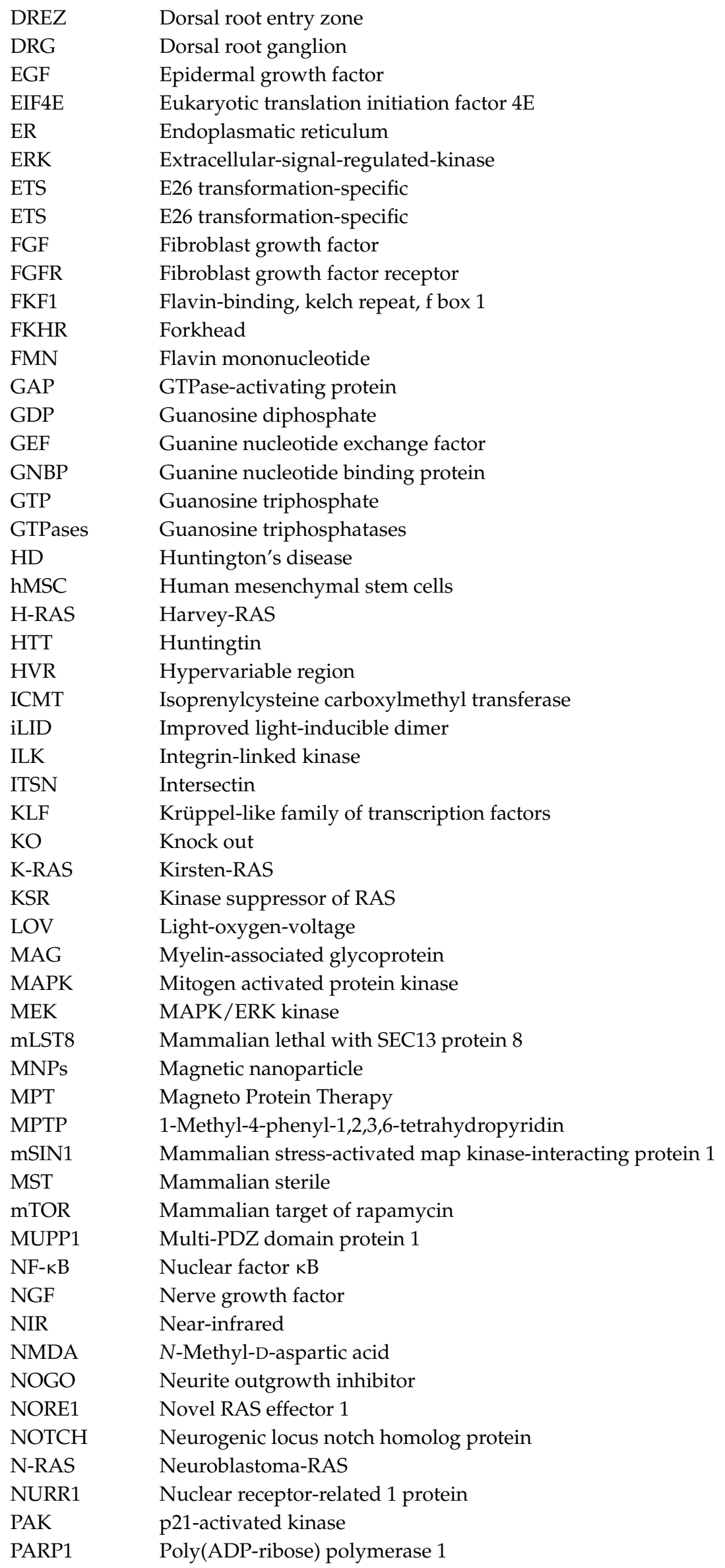




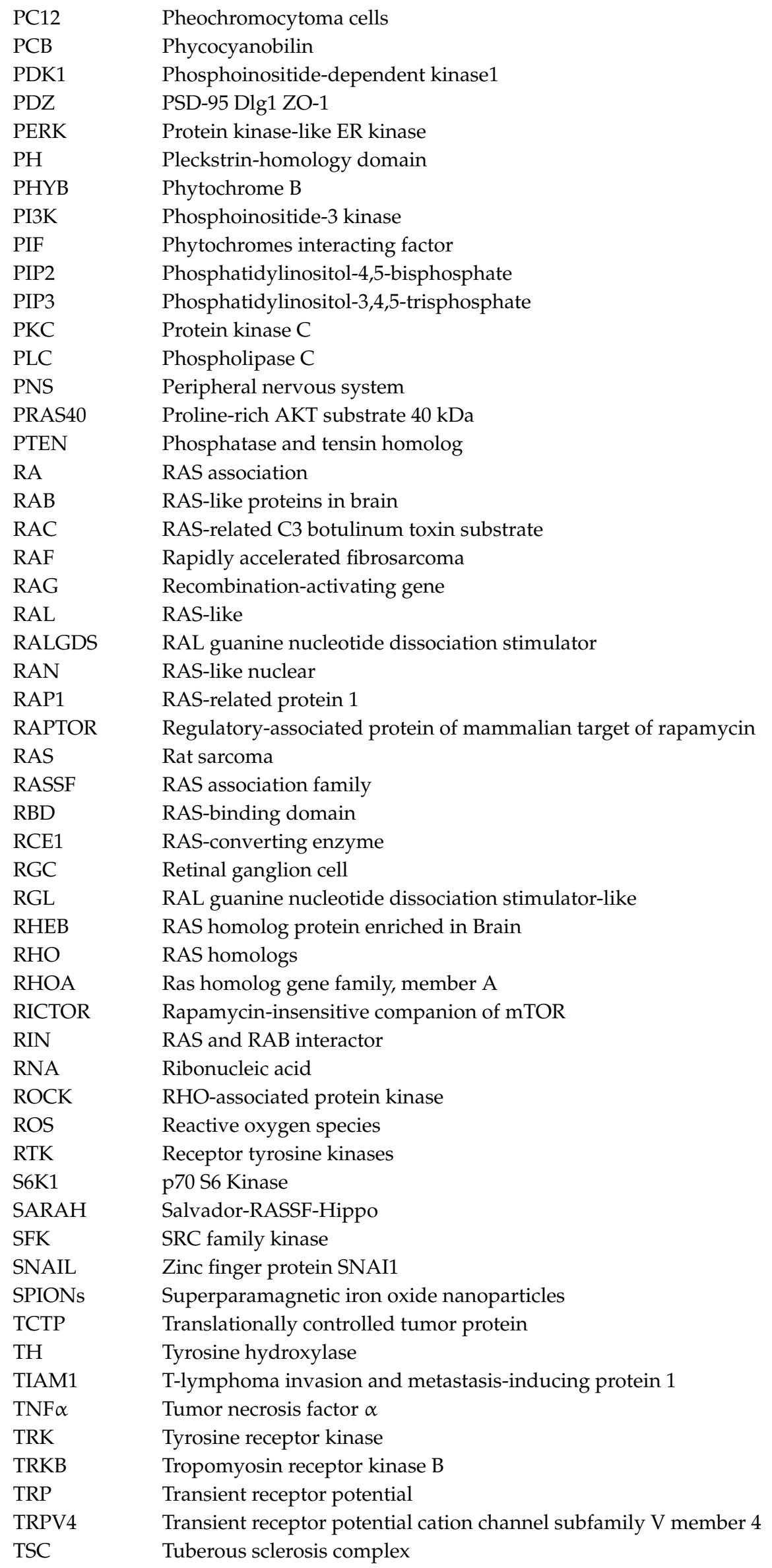




$\begin{array}{ll}\text { TSC1 } & \text { Hamartin } \\ \text { TSC2 } & \text { Tuberin } \\ \text { U2OS } & \text { Human bone osteosarcoma epithelial cell line } \\ \text { ULK1 } & \text { Uncoordinated 51-like kinase } \\ \text { VPS21 } & \text { Vacuolar protein sorting-associated protein 21 } \\ \text { WAVE } & \text { WASP-family verprolin homologous protein } \\ \text { WNT } & \text { int/Wingless } \\ \text { ZO-1 } & \text { Zonula occludens-1 }\end{array}$

\section{References}

1. Wennerberg, K.; Rossman, K.L.; Der, C.J. The ras superfamily at a glance. J. Cell Sci. 2005, 118, 843-846. [CrossRef] [PubMed]

2. Rojas, A.M.; Fuentes, G.; Rausell, A.; Valencia, A. The ras protein superfamily: Evolutionary tree and role of conserved amino acids. J. Cell Biol. 2012, 196, 189-201. [CrossRef] [PubMed]

3. Harvey, J.J. An unidentified virus which causes the rapid production of tumours in mice. Nature 1964, 204, 1104-1105. [CrossRef] [PubMed]

4. Kirsten, W.H.; Mayer, L.A. Morphologic responses to a murine erythroblastosis virus. J. Natl. Cancer Inst. 1967, 39, 311-335. [PubMed]

5. Malumbres, M.; Barbacid, M. Ras oncogenes: The first 30 years. Nat. Rev. Cancer 2003, 3, 459-465. [CrossRef]

6. Urano, J.; Ellis, C.; Clark, G.J.; Tamanoi, F. Characterization of RHEB functions using yeast and mammalian systems. Methods Enzymol. 2001, 333, 217-231. [CrossRef] [PubMed]

7. Heard, J.J.; Fong, V.; Bathaie, S.Z.; Tamanoi, F. Recent progress in the study of the RHEB family gtpases. Cell Signal. 2014, 26, 1950-1957. [CrossRef] [PubMed]

8. Saito, K.; Araki, Y.; Kontani, K.; Nishina, H.; Katada, T. Novel role of the small gtpase RHEB: Its implication in endocytic pathway independent of the activation of mammalian target of rapamycin. J. Biochem. 2005, 137, 423-430. [CrossRef]

9. Yamagata, K.; Sanders, L.K.; Kaufmann, W.E.; Yee, W.; Barnes, C.A.; Nathans, D.; Worley, P.F. RHEB, a growth factor- and synaptic activity-regulated gene, encodes a novel ras-related protein. J. Biol. Chem. 1994, 269, 16333-16339.

10. Vetter, I.R.; Wittinghofer, A. The guanine nucleotide-binding switch in three dimensions. Science 2001, 294, 1299-1304. [CrossRef]

11. Chen, M.; Peters, A.; Huang, T.; Nan, X. Ras dimer formation as a new signaling mechanism and potential cancer therapeutic target. Mini Rev. Med. Chem. 2016, 16, 391-403. [CrossRef] [PubMed]

12. Inouye, K.; Mizutani, S.; Koide, H.; Kaziro, Y. Formation of the ras dimer is essential for raf-1 activation. J. Biol. Chem. 2000, 275, 3737-3740. [CrossRef] [PubMed]

13. Ahearn, I.M.; Haigis, K.; Bar-Sagi, D.; Philips, M.R. Regulating the regulator: Post-translational modification of ras. Nat. Rev. Mol. Cell Biol. 2011, 13, 39-51. [CrossRef] [PubMed]

14. Li, Y.; Zhang, Y.; Grosseruschkamp, F.; Stephan, S.; Cui, Q.; Kotting, C.; Xia, F.; Gerwert, K. Specific substates of ras to interact with gaps and effectors: Revealed by theoretical simulations and ftir experiments. J. Phys. Chem. Lett. 2018, 9, 1312-1317. [CrossRef] [PubMed]

15. Benjamin, D.; Hall, M.N. MTORC1: Turning off is just as important as turning on. Cell 2014, 156, $627-628$. [CrossRef] [PubMed]

16. Ehrkamp, A.; Herrmann, C.; Stoll, R.; Heumann, R. Ras and RHEB signaling in survival and cell death. Cancers 2013, 5, 639-661. [CrossRef] [PubMed]

17. Mitchell, L.; Hobbs, G.A.; Aghajanian, A.; Campbell, S.L. Redox regulation of ras and rho gtpases: Mechanism and function. Antioxid. Redox Signal. 2013, 18, 250-258. [CrossRef] [PubMed]

18. Wolfman, A.; Macara, I.G. A cytosolic protein catalyzes the release of gdp from p21ras. Science 1990, 248, 67-69. [CrossRef]

19. Bos, J.L.; Rehmann, H.; Wittinghofer, A. Gefs and gaps: Critical elements in the control of small g proteins. Cell 2007, 129, 865-877. [CrossRef] 
20. Rehmann, H.; Bruning, M.; Berghaus, C.; Schwarten, M.; Kohler, K.; Stocker, H.; Stoll, R.; Zwartkruis, F.J.; Wittinghofer, A. Biochemical characterisation of tctp questions its function as a guanine nucleotide exchange factor for RHEB. FEBS Lett. 2008, 582, 3005-3010. [CrossRef]

21. Schopel, M.; Potheraveedu, V.N.; Al-Harthy, T.; Abdel-Jalil, R.; Heumann, R.; Stoll, R. The small gtpases ras and RHEB studied by multidimensional nmr spectroscopy: Structure and function. Biol. Chem. 2017, 398, 577-588. [CrossRef] [PubMed]

22. Hancock, J.F.; Parton, R.G. Ras plasma membrane signalling platforms. Biochem. J. 2005, 389, 1-11. [CrossRef] [PubMed]

23. Li, Y.; Inoki, K.; Guan, K.-L. Biochemical and functional characterizations of small gtpase RHEB and TSC2 gap activity. Mol. Cell. Biol. 2004, 24, 7965-7975. [CrossRef] [PubMed]

24. Rajalingam, K.; Schreck, R.; Rapp, U.R.; Albert, S. Ras oncogenes and their downstream targets. Biochim. Biophys. Acta 2007, 1773, 1177-1195. [CrossRef] [PubMed]

25. Chen, Z.; Otto, J.C.; Bergo, M.O.; Young, S.G.; Casey, P.J. The c-terminal polylysine region and methylation of k-ras are critical for the interaction between k-ras and microtubules. J. Biol. Chem. 2000, 275, 41251-41257. [CrossRef] [PubMed]

26. Thissen, J.A.; Gross, J.M.; Subramanian, K.; Meyer, T.; Casey, P.J. Prenylation-dependent association of ki-ras with microtubules. Evidence for a role in subcellular trafficking. J. Biol. Chem. 1997, 272, 30362-30370. [CrossRef] [PubMed]

27. Schmick, M.; Vartak, N.; Papke, B.; Kovacevic, M.; Truxius, D.C.; Rossmannek, L.; Bastiaens, P.I.H. Kras localizes to the plasma membrane by spatial cycles of solubilization, trapping and vesicular transport. Cell 2014, 157, 459-471. [CrossRef] [PubMed]

28. Jura, N.; Scotto-Lavino, E.; Sobczyk, A.; Bar-Sagi, D. Differential modification of ras proteins by ubiquitination. Mol. Cell 2006, 21, 679-687. [CrossRef] [PubMed]

29. Buerger, C.; DeVries, B.; Stambolic, V. Localization of RHEB to the endomembrane is critical for its signaling function. Biochem. Biophys. Res. Commun. 2006, 344, 869-880. [CrossRef] [PubMed]

30. Sancak, Y.; Thoreen, C.C.; Peterson, T.R.; Lindquist, R.A.; Kang, S.A.; Spooner, E.; Carr, S.A.; Sabatini, D.M. Pras40 is an insulin-regulated inhibitor of the mTORC1 protein kinase. Mol. Cell 2007, 25, 903-915. [CrossRef] [PubMed]

31. Takahashi, K.; Nakagawa, M.; Young, S.G.; Yamanaka, S. Differential membrane localization of eras and RHEB, two ras-related proteins involved in the phosphatidylinositol 3-kinase/mtor pathway. J. Biol. Chem. 2005, 280, 32768-32774. [CrossRef] [PubMed]

32. Lavoie, H.; Therrien, M. Regulation of raf protein kinases in erk signalling. Nat. Rev. Mol. Cell Biol. 2015, 16, 281-298. [CrossRef] [PubMed]

33. Matallanas, D.; Birtwistle, M.; Romano, D.; Zebisch, A.; Rauch, J.; von Kriegsheim, A.; Kolch, W. Raf family kinases: Old dogs have learned new tricks. Genes Cancer 2011, 2, 232-260. [CrossRef] [PubMed]

34. Baljuls, A.; Kholodenko, B.N.; Kolch, W. It takes two to tango-Signalling by dimeric raf kinases. Mol. bioSyst. 2013, 9, 551-558. [CrossRef] [PubMed]

35. Zhou, Y.; Hancock, J.F. Ras nanoclusters: Versatile lipid-based signaling platforms. Biochim. Biophys. Acta 2015, 1853, 841-849. [CrossRef] [PubMed]

36. Jin, T.G.; Satoh, T.; Liao, Y.; Song, C.; Gao, X.; Kariya, K.; Hu, C.D.; Kataoka, T. Role of the cdc25 homology domain of phospholipase cepsilon in amplification of rap1-dependent signaling. J. Biol. Chem. 2001, 276, 30301-30307. [CrossRef]

37. Hay, N.; Sonenberg, N. Upstream and downstream of mtor. Genes Dev. 2004, 18, 1926-1945. [CrossRef]

38. Peng, H.; Kasada, A.; Ueno, M.; Hoshii, T.; Tadokoro, Y.; Nomura, N.; Ito, C.; Takase, Y.; Vu, H.T.; Kobayashi, M.; et al. Distinct roles of RHEB and raptor in activating mtor complex 1 for the self-renewal of hematopoietic stem cells. Biochem. Biophys. Res. Commun. 2018, 495, 1129-1135. [CrossRef]

39. Jacinto, E.; Loewith, R.; Schmidt, A.; Lin, S.; Rüegg, M.A.; Hall, A.; Hall, M.N. Mammalian tor complex 2 controls the actin cytoskeleton and is rapamycin insensitive. Nat. Cell Biol. 2004, 6, 1122. [CrossRef]

40. Kim, D.-H.; Sarbassov, D.D.; Ali, S.M.; Latek, R.R.; Guntur, K.V.P.; Erdjument-Bromage, H.; Tempst, P.; Sabatini, D.M. G $\beta 1$, a positive regulator of the rapamycin-sensitive pathway required for the nutrient-sensitive interaction between raptor and mtor. Mol. Cell 2003, 11, 895-904. [CrossRef] 
41. Peterson, T.R.; Laplante, M.; Thoreen, C.C.; Sancak, Y.; Kang, S.A.; Kuehl, W.M.; Gray, N.S.; Sabatini, D.M. Deptor is an mtor inhibitor frequently overexpressed in multiple myeloma cells and required for their survival. Cell 2009, 137, 873-886. [CrossRef] [PubMed]

42. Kaizuka, T.; Hara, T.; Oshiro, N.; Kikkawa, U.; Yonezawa, K.; Takehana, K.; Iemura, S.-I.; Natsume, T.; Mizushima, N. Tti1 and tel2 are critical factors in mammalian target of rapamycin complex assembly. J. Biol. Chem. 2010, 285, 20109-20116. [CrossRef] [PubMed]

43. Hara, K.; Maruki, Y.; Long, X.; Yoshino, K.-I.; Oshiro, N.; Hidayat, S.; Tokunaga, C.; Avruch, J.; Yonezawa, K. Raptor, a binding partner of target of rapamycin (tor), mediates tor action. Cell 2002, 110, 177-189. [CrossRef]

44. Kim, D.-H.; Sarbassov, D.D.; Ali, S.M.; King, J.E.; Latek, R.R.; Erdjument-Bromage, H.; Tempst, P.; Sabatini, D.M. Mtor interacts with raptor to form a nutrient-sensitive complex that signals to the cell growth machinery. Cell 2002, 110, 163-175. [CrossRef]

45. Thedieck, K.; Polak, P.; Kim, M.L.; Molle, K.D.; Cohen, A.; Jenö, P.; Arrieumerlou, C.; Hall, M.N. Pras40 and prr5-like protein are new mtor interactors that regulate apoptosis. PLoS ONE 2007, 2, e1217. [CrossRef] [PubMed]

46. Wang, L.; Harris, T.E.; Roth, R.A.; Lawrence, J.C. Pras40 regulates mTORC1 kinase activity by functioning as a direct inhibitor of substrate binding. J. Biol. Chem. 2007, 282, 20036-20044. [CrossRef] [PubMed]

47. Long, X.; Lin, Y.; Ortiz-Vega, S.; Yonezawa, K.; Avruch, J. RHEB binds and regulates the mtor kinase. Curr. Biol. 2005, 15, 702-713. [CrossRef]

48. Dos, D.S.; Ali, S.M.; Kim, D.-H.; Guertin, D.A.; Latek, R.R.; Erdjument-Bromage, H.; Tempst, P.; Sabatini, D.M. Rictor, a novel binding partner of mtor, defines a rapamycin-insensitive and raptor-independent pathway that regulates the cytoskeleton. Curr. Biol. 2004, 14, 1296-1302. [CrossRef]

49. Frias, M.A.; Thoreen, C.C.; Jaffe, J.D.; Schroder, W.; Sculley, T.; Carr, S.A.; Sabatini, D.M. Msin1 is necessary for akt/pkb phosphorylation, and its isoforms define three distinct mTORC2s. Curr. Biol. 2006, 16, 1865-1870. [CrossRef]

50. Pearce, L.R.; Huang, X.; Boudeau, J.; Pawłowski, R.; Wullschleger, S.; Deak, M.; Ibrahim, A.F.; Gourlay, R.; Magnuson, M.A.; Alessi, D.R. Identification of protor as a novel rictor-binding component of mtor complex-2. Biochem. J. 2007, 405, 513-522. [CrossRef]

51. Burnett, P.E.; Barrow, R.K.; Cohen, N.A.; Snyder, S.H.; Sabatini, D.M. Raft1 phosphorylation of the translational regulators p70 s6 kinase and 4e-bp1. Proc. Natl. Acad. Sci. USA 1998, 95, 1432-1437. [CrossRef] [PubMed]

52. Chung, J.; Kuo, C.J.; Crabtree, G.R.; Blenis, J. Rapamycin-fkbp specifically blocks growth-dependent activation of and signaling by the $70 \mathrm{kd} \mathrm{s} 6$ protein kinases. Cell 1992, 69, 1227-1236. [CrossRef]

53. Kuo, C.J.; Chung, J.; Fiorentino, D.F.; Flanagan, W.M.; Blenis, J.; Crabtree, G.R. Rapamycin selectively inhibits interleukin-2 activation of p70 s6 kinase. Nature 1992, 358, 70. [CrossRef] [PubMed]

54. Ma, X.M.; Blenis, J. Molecular mechanisms of mtor-mediated translational control. Nat. Rev. Mol. Cell Biol. 2009, 10, 307. [CrossRef] [PubMed]

55. Hosokawa, N.; Hara, T.; Kaizuka, T.; Kishi, C.; Takamura, A.; Miura, Y.; Iemura, S.-I.; Natsume, T.; Takehana, K.; Yamada, N.; et al. Nutrient-dependent mTORC1 association with the ulk1-atg13-fip200 complex required for autophagy. Mol. Biol. Cell 2009, 20, 1981-1991. [CrossRef] [PubMed]

56. Schmidt, A.; Bickle, M.; Beck, T.; Hall, M.N. The yeast phosphatidylinositol kinase homolog tor2 activates rho1 and rho2 via the exchange factor rom2. Cell 1997, 88, 531-542. [CrossRef]

57. Rodriguez-Viciana, P.; Warne, P.H.; Dhand, R.; Vanhaesebroeck, B.; Gout, I.; Fry, M.J.; Waterfield, M.D.; Downward, J. Phosphatidylinositol-3-oh kinase as a direct target of ras. Nature 1994, 370, 527-532. [CrossRef]

58. Courtney, K.D.; Corcoran, R.B.; Engelman, J.A. The PI3K pathway as drug target in human cancer. J. Clin. Oncol. 2010, 28, 1075-1083. [CrossRef]

59. Feinstein, E. Ral-gtpases: Good chances for a long-lasting fame. Oncogene 2005, 24, 326. [CrossRef]

60. Teodoro, R.O.; Pekkurnaz, G.; Nasser, A.; Higashi-Kovtun, M.E.; Balakireva, M.; McLachlan, I.G.; Camonis, J.; Schwarz, T.L. Ral mediates activity-dependent growth of postsynaptic membranes via recruitment of the exocyst. EMBO J. 2013, 32, 2039-2055. [CrossRef]

61. Rosse, C.; Hatzoglou, A.; Parrini, M.C.; White, M.A.; Chavrier, P.; Camonis, J. Ralb mobilizes the exocyst to drive cell migration. Mol. Cell. Biol. 2006, 26, 727-734. [CrossRef] [PubMed]

62. Camonis, J.H.; White, M.A. Ral gtpases: Corrupting the exocyst in cancer cells. Trends Cell Biol. 2005, 15, 327-332. [CrossRef] [PubMed] 
63. Feig, L.A. Ral-gtpases: Approaching their 15 minutes of fame. Trends Cell Biol. 2003, 13, 419-425. [CrossRef]

64. Martin, T.D.; Chen, X.W.; Kaplan, R.E.; Saltiel, A.R.; Walker, C.L.; Reiner, D.J.; Der, C.J. Ral and RHEB gtpase activating proteins integrate mtor and gtpase signaling in aging, autophagy, and tumor cell invasion. Mol. Cell 2014, 53, 209-220. [CrossRef] [PubMed]

65. Lalli, G.; Hall, A. Ral gtpases regulate neurite branching through gap-43 and the exocyst complex. J. Cell Biol. 2005, 171, 857-869. [CrossRef] [PubMed]

66. Lambert, J.M.; Lambert, Q.T.; Reuther, G.W.; Malliri, A.; Siderovski, D.P.; Sondek, J.; Collard, J.G.; Der, C.J. Tiam1 mediates ras activation of rac by a pi(3)k-independent mechanism. Nat. Cell Biol. 2002, 4, 621-625. [CrossRef] [PubMed]

67. Yamauchi, J.; Miyamoto, Y.; Tanoue, A.; Shooter, E.M.; Chan, J.R. Ras activation of a rac1 exchange factor, tiam1, mediates neurotrophin-3-induced schwann cell migration. Proc. Natl. Acad. Sci. USA 2005, 102, 14889-14894. [CrossRef]

68. Arthur, W.T.; Quilliam, L.A.; Cooper, J.A. Rap1 promotes cell spreading by localizing rac guanine nucleotide exchange factors. J. Cell Biol. 2004, 167, 111-122. [CrossRef]

69. Demarco, R.S.; Struckhoff, E.C.; Lundquist, E.A. The rac gtp exchange factor tiam-1 acts with cdc-42 and the guidance receptor unc-40/dcc in neuronal protrusion and axon guidance. PLoS Genet. 2012, 8, e1002665. [CrossRef]

70. Ehler, E.; van Leeuwen, F.; Collard, J.G.; Salinas, P.C. Expression of tiam-1 in the developing brain suggests a role for the tiam-1-rac signaling pathway in cell migration and neurite outgrowth. Mol. Cell. Neurosci. 1997, 9, 1-12. [CrossRef]

71. Zheng, C.; Diaz-Cuadros, M.; Chalfie, M. Gefs and rac gtpases control directional specificity of neurite extension along the anterior-posterior axis. Proc. Natl. Acad. Sci. USA 2016, 113, 6973-6978. [CrossRef] [PubMed]

72. Tall, G.G.; Barbieri, M.A.; Stahl, P.D.; Horazdovsky, B.F. Ras-activated endocytosis is mediated by the rab5 guanine nucleotide exchange activity of rin1. Dev. Cell 2001, 1, 73-82. [CrossRef]

73. Doi, M.; Minematsu, H.; Kubota, Y.; Nishiwaki, K.; Miyamoto, M. The novel rac effector rin-1 regulates neuronal cell migration and axon pathfinding in C. elegans. Development 2013, 140, 3435-3444. [CrossRef] [PubMed]

74. Song, C.; Satoh, T.; Edamatsu, H.; Wu, D.; Tadano, M.; Gao, X.; Kataoka, T. Differential roles of ras and rap1 in growth factor-dependent activation of phospholipase C epsilon. Oncogene 2002, 21, 8105-8113. [CrossRef]

75. Zhadanov, A.B.; Provance, D.W., Jr.; Speer, C.A.; Coffin, J.D.; Goss, D.; Blixt, J.A.; Reichert, C.M.; Mercer, J.A. Absence of the tight junctional protein af- 6 disrupts epithelial cell-cell junctions and cell polarity during mouse development. Curr. Biol. 1999, 9, 880-888. [CrossRef]

76. Zhang, Z.; Rehmann, H.; Price, L.S.; Riedl, J.; Bos, J.L. Af6 negatively regulates rap1-induced cell adhesion. J. Biol. Chem. 2005, 280, 33200-33205. [CrossRef] [PubMed]

77. Toker, A. Signaling through protein kinase C. Front. Biosci. 1998, 3, D1134-D1147. [CrossRef] [PubMed]

78. Marshall, M.S. Ras target proteins in eukaryotic cells. FASEB J. 1995, 9, 1311-1318. [CrossRef] [PubMed]

79. Kuriyama, M.; Harada, N.; Kuroda, S.; Yamamoto, T.; Nakafuku, M.; Iwamatsu, A.; Yamamoto, D.; Prasad, R.; Croce, C.; Canaani, E.; et al. Identification of af- 6 and canoe as putative targets for ras. J. Biol. Chem. 1996, 271, 607-610. [CrossRef] [PubMed]

80. Li, X.; Lynn, B.D.; Nagy, J.I. The effector and scaffolding proteins af6 and mupp1 interact with connexin36 and localize at gap junctions that form electrical synapses in rodent brain. Eur. J. Neurosci. 2012, 35, 166-181. [CrossRef] [PubMed]

81. Carmena, A.; Speicher, S.; Baylies, M. The pdz protein canoe/af-6 links ras-mapk, notch and wingless/wnt signaling pathways by directly interacting with ras, notch and dishevelled. PLoS ONE 2006, 1, e66. [CrossRef]

82. Boettner, B.; Harjes, P.; Ishimaru, S.; Heke, M.; Fan, H.Q.; Qin, Y.; Van Aelst, L.; Gaul, U. The af-6 homolog canoe acts as a rap1 effector during dorsal closure of the drosophila embryo. Genetics 2003, 165, 159-169. [PubMed]

83. Speicher, S.; Fischer, A.; Knoblich, J.; Carmena, A. The pdz protein canoe regulates the asymmetric division of drosophila neuroblasts and muscle progenitors. Curr. Biol. 2008, 18, 831-837. [CrossRef] [PubMed]

84. Donninger, H.; Schmidt, M.L.; Mezzanote, J.; Barnoud, T.; Clark, G.J. Ras signaling through rassf proteins. Semin. Cell Dev. Biol. 2016, 58, 86-95. [CrossRef] [PubMed] 
85. Zhong, J. Ras and downstream raf-mek and PI3K-akt signaling in neuronal development, function and dysfunction. Biol. Chem. 2016, 397, 215-222. [CrossRef] [PubMed]

86. Potheraveedu, V.N.; Schöpel, M.; Stoll, R.; Heumann, R. RHEB in neuronal degeneration, regeneration, and connectivity. Biol. Chem. 2017, 398, 589-606. [CrossRef] [PubMed]

87. Thomanetz, V.; Angliker, N.; Cloëtta, D.; Lustenberger, R.M.; Schweighauser, M.; Oliveri, F.; Suzuki, N.; Rüegg, M.A. Ablation of the mTORC2 component rictor in brain or purkinje cells affects size and neuron morphology. J. Cell Biol. 2013, 201, 293-308. [CrossRef] [PubMed]

88. Urbanska, M.; Gozdz, A.; Swiech, L.J.; Jaworski, J. Mammalian target of rapamycin complex 1 (mTORC1) and 2 (mTORC2) control the dendritic arbor morphology of hippocampal neurons. J. Biol. Chem. 2012, 287, 30240-30256. [CrossRef] [PubMed]

89. Fritsche-Guenther, R.; Witzel, F.; Kempa, S.; Brummer, T.; Sers, C.; Blüthgen, N. Effects of raf inhibitors on $\mathrm{PI}$ KK/akt signalling depend on mutational status of the ras/raf signalling axis. Oncotarget 2016, 7, 7960-7969. [CrossRef] [PubMed]

90. Borasio, G.D.; John, J.; Wittinghofer, A.; Barde, Y.A.; Sendtner, M.; Heumann, R. Ras p21 protein promotes survival and fiber outgrowth of cultured embryonic neurons. Neuron 1989, 2, 1087-1096. [CrossRef]

91. Anderson, C.N.; Tolkovsky, A.M. A role for mapk/erk in sympathetic neuron survival: Protection against a p53-dependent, jnk-independent induction of apoptosis by cytosine arabinoside. J. Neurosci. 1999, 19, 664-673. [CrossRef]

92. Bonni, A.; Brunet, A.; West, A.E.; Datta, S.R.; Takasu, M.A.; Greenberg, M.E. Cell survival promoted by the ras-mapk signaling pathway by transcription-dependent and -independent mechanisms. Science 1999, 286, 1358-1362. [CrossRef] [PubMed]

93. Xifro, X.; Minano-Molina, A.J.; Saura, C.A.; Rodriguez-Alvarez, J. Ras protein activation is a key event in activity-dependent survival of cerebellar granule neurons. J. Biol. Chem. 2014, 289, 8462-8472. [CrossRef] [PubMed]

94. Walker, S.A.; Kupzig, S.; Bouyoucef, D.; Davies, L.C.; Tsuboi, T.; Bivona, T.G.; Cozier, G.E.; Lockyer, P.J.; Buckler, A.; Rutter, G.A.; et al. Identification of a ras gtpase-activating protein regulated by receptor-mediated $\mathrm{Ca}^{2+}$ oscillations. EMBO J. 2004, 23, 1749-1760. [CrossRef] [PubMed]

95. Walker, S.A.; Cullen, P.J.; Taylor, J.A.; Lockyer, P.J. Control of ras cycling by Ca ${ }^{2+}$. FEBS Lett. 2003, 546, 6-10. [CrossRef]

96. Heumann, R.; Goemans, C.; Bartsch, D.; Lingenhöhl, K.; Waldmeier, P.C.; Hengerer, B.; Allegrini, P.R.; Schellander, K.; Wagner, E.F.; Arendt, T.; et al. Transgenic activation of ras in neurons promotes hypertrophy and protects from lesion-induced degeneration. J. Cell Biol. 2000, 151, 1537-1548. [CrossRef]

97. Gärtner, U.; Alpár, A.; Seeger, G.; Heumann, R.; Arendt, T. Enhanced ras activity in pyramidal neurons induces cellular hypertrophy and changes in afferent and intrinsic connectivity in synras mice. Int. J. Dev. Neurosci. 2004, 22, 165-173. [CrossRef] [PubMed]

98. Felderhoff-Mueser, U.; Bittigau, P.; Sifringer, M.; Jarosz, B.; Korobowicz, E.; Mahler, L.; Piening, T.; Moysich, A.; Grune, T.; Thor, F.; et al. Oxygen causes cell death in the developing brain. Neurobiol. Dis. 2004, 17, 273-282. [CrossRef]

99. Chan, C.B.; Liu, X.; Pradoldej, S.; Hao, C.; An, J.; Yepes, M.; Luo, H.R.; Ye, K. Phosphoinositide 3-kinase enhancer regulates neuronal dendritogenesis and survival in neocortex. J. Neurosci. 2011, 31, 8083-8092. [CrossRef]

100. Leinninger, G.M.; Backus, C.; Uhler, M.D.; Lentz, S.I.; Feldman, E.L. Phosphatidylinositol 3-kinase and akt effectors mediate insulin-like growth factor-i neuroprotection in dorsal root ganglia neurons. FASEB J. 2004, 18, 1544-1546. [CrossRef]

101. Anderton, R.S.; Price, L.L.; Turner, B.J.; Meloni, B.P.; Mitrpant, C.; Mastaglia, F.L.; Goh, C.; Wilton, S.D.; Boulos, S. Co-regulation of survival of motor neuron and bcl-xl expression: Implications for neuroprotection in spinal muscular atrophy. Neuroscience 2012, 220, 228-236. [CrossRef]

102. Markus, A.; Zhong, J.; Snider, W.D. Raf and akt mediate distinct aspects of sensory axon growth. Neuron 2002, 35, 65-76. [CrossRef]

103. Orike, N.; Middleton, G.; Borthwick, E.; Buchman, V.; Cowen, T.; Davies, A.M. Role of pi 3-kinase, akt and bcl-2-related proteins in sustaining the survival of neurotrophic factor-independent adult sympathetic neurons. J. Cell Biol. 2001, 154, 995-1005. [CrossRef] 
104. Dudek, H.; Datta, S.R.; Franke, T.F.; Birnbaum, M.J.; Yao, R.; Cooper, G.M.; Segal, R.A.; Kaplan, D.R.; Greenberg, M.E. Regulation of neuronal survival by the serine-threonine protein kinase akt. Science 1997, 275, 661-665. [CrossRef] [PubMed]

105. Brunet, A.; Datta, S.R.; Greenberg, M.E. Transcription-dependent and -independent control of neuronal survival by the PI3K-akt signaling pathway. Curr. Opin. Neurobiol. 2001, 11, 297-305. [CrossRef]

106. Chakrabarty, K.; Serchov, T.; Mann, S.A.; Dietzel, I.D.; Heumann, R. Enhancement of dopaminergic properties and protection mediated by neuronal activation of ras in mouse ventral mesencephalic neurones. Eur. J. Neurosci. 2007, 25, 1971-1981. [CrossRef]

107. Arya, R.; White, K. Cell death in development: Signaling pathways and core mechanisms. Semin. Cell Dev. Biol. 2015, 39, 12-19. [CrossRef] [PubMed]

108. Kerr, J.F.; Wyllie, A.H.; Currie, A.R. Apoptosis: A basic biological phenomenon with wide-ranging implications in tissue kinetics. Br. J. Cancer 1972, 26, 239-257. [CrossRef]

109. Gulbins, E.; Brenner, B.; Koppenhoefer, U.; Linderkamp, O.; Lang, F. Fas or ceramide induce apoptosis by ras-regulated phosphoinositide-3-kinase activation. J. Leukoc. Biol. 1998, 63, 253-263. [CrossRef]

110. Overmeyer, J.H.; Kaul, A.; Johnson, E.E.; Maltese, W.A. Active ras triggers death in glioblastoma cells through hyperstimulation of macropinocytosis. Mol. Cancer Res. 2008, 6, 965-977. [CrossRef] [PubMed]

111. Li, D.W.C.; Liu, J.P.; Mao, Y.W.; Xiang, H.; Wang, J.; Ma, W.Y.; Dong, Z.G.; Pike, H.M.; Brown, R.E.; Reed, J.C. Calcium-activated raf/mek/erk signaling pathway mediates p53-dependent apoptosis and is abrogated by alpha b-crystallin through inhibition of ras activation. Mol. Biol. Cell 2005, 16, 4437-4453. [CrossRef] [PubMed]

112. Kang, J.; Pervaiz, S. Crosstalk between bcl-2 family and ras family small gtpases: Potential cell fate regulation? Front. Oncol. 2012, 2, 206. [CrossRef] [PubMed]

113. Richter, A.M.; Pfeifer, G.P.; Dammann, R.H. The rassf proteins in cancer; from epigenetic silencing to functional characterization. Biochim. Biophys. Acta 2009, 1796, 114-128. [CrossRef] [PubMed]

114. Gordon, M.; Baksh, S. Rassf1a: Not a prototypical ras effector. Small GTPases 2011, 2, 148-157. [CrossRef] [PubMed]

115. Volodko, N.; Gordon, M.; Salla, M.; Ghazaleh, H.A.; Baksh, S. Rassf tumor suppressor gene family: Biological functions and regulation. FEBS Lett. 2014, 588, 2671-2684. [CrossRef] [PubMed]

116. Sherwood, V.; Recino, A.; Jeffries, A.; Ward, A.; Chalmers, A.D. The n-terminal rassf family: A new group of ras-association-domain-containing proteins, with emerging links to cancer formation. Biochem. J. 2009, 425, 303-311. [CrossRef] [PubMed]

117. Vavvas, D.; Li, X.; Avruch, J.; Zhang, X.F. Identification of nore1 as a potential ras effector. J. Biol. Chem. 1998, 273, 5439-5442. [CrossRef] [PubMed]

118. Park, J.; Kang, S.I.; Lee, S.Y.; Zhang, X.F.; Kim, M.S.; Beers, L.F.; Lim, D.S.; Avruch, J.; Kim, H.S.; Lee, S.B. Tumor suppressor ras association domain family 5 (rassf5/nore1) mediates death receptor ligand-induced apoptosis. J. Biol. Chem. 2010, 285, 35029-35038. [CrossRef] [PubMed]

119. Elmetwali, T.; Salman, A.; Palmer, D.H. Nore1a induction by membrane-bound cd401 (mcd401) contributes to cd401-induced cell death and g1 growth arrest in p21-mediated mechanism. Cell Death Dis. 2016, 7, e2146. [CrossRef]

120. Khokhlatchev, A.; Rabizadeh, S.; Xavier, R.; Nedwidek, M.; Chen, T.; Zhang, X.F.; Seed, B.; Avruch, J. Identification of a novel ras-regulated proapoptotic pathway. Curr. Biol. 2002, 12, 253-265. [CrossRef]

121. Koturenkiene, A.; Makbul, C.; Herrmann, C.; Constantinescu-Aruxandei, D. Kinetic characterization of apoptotic ras signaling through nore1-mst1 complex formation. Biol. Chem. 2017, 398, 701-707. [CrossRef] [PubMed]

122. Chen, S.; Fang, Y.J.; Xu, S.B.; Reis, C.; Zhang, J.M. Mammalian sterile20-like kinases: Signalings and roles in central nervous system. Aging Dis. 2018, 9, 537-552. [CrossRef] [PubMed]

123. Titus, H.E.; Lopez-Juarez, A.; Silbak, S.H.; Rizvi, T.A.; Bogard, M.; Ratner, N. Oligodendrocyte rasg12v expressed in its endogenous locus disrupts myelin structure through increased mapk, nitric oxide, and notch signaling. Glia 2017, 65, 1990-2002. [CrossRef] [PubMed]

124. Serdar, M.; Herz, J.; Kempe, K.; Winterhager, E.; Jastrow, H.; Heumann, R.; Felderhoff-Muser, U.; Bendix, I. Protection of oligodendrocytes through neuronal overexpression of the small gtpase ras in hyperoxia-induced neonatal brain injury. Front. Neurol. 2018, 9, 175. [CrossRef] [PubMed] 
125. Aoki, Y.; Niihori, T.; Kawame, H.; Kurosawa, K.; Ohashi, H.; Tanaka, Y.; Filocamo, M.; Kato, K.; Suzuki, Y.; Kure, S.; et al. Germline mutations in hras proto-oncogene cause costello syndrome. Nat. Genet. 2005, 37, 1038-1040. [CrossRef] [PubMed]

126. Menon, S.; Dibble, C.C.; Talbott, G.; Hoxhaj, G.; Valvezan, A.J.; Takahashi, H.; Cantley, L.C.; Manning, B.D. Spatial control of the TSC complex integrates insulin and nutrient regulation of mTORC1 at the lysosome. Cell 2014, 156, 771-785. [CrossRef] [PubMed]

127. Dibble, C.C.; Cantley, L.C. Regulation of mTORC1 by PI3K signaling. Trends Cell Biol. 2015, 25, 545-555. [CrossRef]

128. Sancak, Y.; Peterson, T.R.; Shaul, Y.D.; Lindquist, R.A.; Thoreen, C.C.; Bar-Peled, L.; Sabatini, D.M. The rag gtpases bind raptor and mediate amino acid signaling to mTORC1. Science 2008, 320, 1496-1501. [CrossRef]

129. Demetriades, C.; Doumpas, N.; Teleman, A.A. Regulation of TORC1 in response to amino acid starvation via lysosomal recruitment of TSC2. Cell 2014, 156, 786-799. [CrossRef]

130. Patel, P.H.; Tamanoi, F. Increased RHEB-tor signaling enhances sensitivity of the whole organism to oxidative stress. J. Cell Sci. 2006, 119, 4285-4292. [CrossRef]

131. Yoshida, S.; Hong, S.; Suzuki, T.; Nada, S.; Mannan, A.M.; Wang, J.; Okada, M.; Guan, K.-L.; Inoki, K. Redox regulates mammalian target of rapamycin complex 1 (mTORC1) activity by modulating the TSC1/TSC2-RHEB gtpase pathway. J. Biol. Chem. 2011, 286, 32651-32660. [CrossRef] [PubMed]

132. Di Nardo, A.; Kramvis, I.; Cho, N.; Sadowski, A.; Meikle, L.; Kwiatkowski, D.J.; Sahin, M. Tuberous sclerosis complex activity is required to control neuronal stress responses in an mtor-dependent manner. J. Neurosci. 2009, 29, 5926-5937. [CrossRef]

133. Lee, H.; Paik, S.G. Regulation of BNIP3 in normal and cancer cells. Mol. Cells 2006, 21, 1-6. [PubMed]

134. Li, Y.; Wang, Y.; Kim, E.; Beemiller, P.; Wang, C.-Y.; Swanson, J.; You, M.; Guan, K.-L. BNIP3 mediates the hypoxia-induced inhibition on mammalian target of rapamycin by interacting with RHEB. J. Biol. Chem. 2007, 282, 35803-35813. [CrossRef] [PubMed]

135. Kita, K.; Wu, Y.P.; Sugaya, S.; Moriya, T.; Nomura, J.; Takahashi, S.; Yamamori, H.; Nakajima, N.; Suzuki, N. Search for UV-responsive genes in human cells by differential mRNA display: Involvement of human ras-related GTP-binding protein, RHEB, in UV susceptibility. Biochem. Biophys. Res. Commun. 2000, 274, 859-864. [CrossRef] [PubMed]

136. Cao, M.; Tan, X.; Jin, W.; Zheng, H.; Xu, W.; Rui, Y.; Li, L.; Cao, J.; Wu, X.; Cui, G.; et al. Upregulation of ras homolog enriched in the brain (RHEB) in lipopolysaccharide-induced neuroinflammation. Neurochem. Int. 2013, 62, 406-417. [CrossRef] [PubMed]

137. Norsted Gregory, E.; Codeluppi, S.; Gregory, J.A.; Steinauer, J.; Svensson, C.I. Mammalian target of rapamycin in spinal cord neurons mediates hypersensitivity induced by peripheral inflammation. Neuroscience 2010, 169, 1392-1402. [CrossRef] [PubMed]

138. Karassek, S.; Berghaus, C.; Schwarten, M.; Goemans, C.G.; Ohse, N.; Kock, G.; Jockers, K.; Neumann, S.; Gottfried, S.; Herrmann, C.; et al. Ras homolog enriched in brain (RHEB) enhances apoptotic signaling. J. Biol. Chem. 2010, 285, 33979-33991. [CrossRef]

139. Soga, M.; Matsuzawa, A.; Ichijo, H. Oxidative stress-induced diseases via the ASK1 signaling pathway. Int. J. Cell Biol. 2012, 2012, 1-5. [CrossRef]

140. Klionsky, D.J. Autophagy: From phenomenology to molecular understanding in less than a decade. Nat. Rev. Mol. Cell Biol. 2007, 8, 931-937. [CrossRef]

141. Ravikumar, B.; Duden, R.; Rubinsztein, D.C. Aggregate-prone proteins with polyglutamine and polyalanine expansions are degraded by autophagy. Hum. Mol. Genet. 2002, 11, 1107-1117. [CrossRef] [PubMed]

142. Webb, J.L.; Ravikumar, B.; Atkins, J.; Skepper, J.N.; Rubinsztein, D.C. Alpha-synuclein is degraded by both autophagy and the proteasome. J. Biol. Chem. 2003, 278, 25009-25013. [CrossRef] [PubMed]

143. Iwata, A.; Riley, B.E.; Johnston, J.A.; Kopito, R.R. Hdac6 and microtubules are required for autophagic degradation of aggregated huntingtin. J. Biol. Chem. 2005, 280, 40282-40292. [CrossRef] [PubMed]

144. Ozcan, U.; Ozcan, L.; Yilmaz, E.; Duvel, K.; Sahin, M.; Manning, B.D.; Hotamisligil, G.S. Loss of the tuberous sclerosis complex tumor suppressors triggers the unfolded protein response to regulate insulin signaling and apoptosis. Mol. Cell 2008, 29, 541-551. [CrossRef]

145. Yokouchi, M.; Hiramatsu, N.; Hayakawa, K.; Okamura, M.; Du, S.; Kasai, A.; Takano, Y.; Shitamura, A.; Shimada, T.; Yao, J.; et al. Involvement of selective reactive oxygen species upstream of proapoptotic branches of unfolded protein response. J. Biol. Chem. 2008, 283, 4252-4260. [CrossRef] [PubMed] 
146. Hinerfeld, D.; Traini, M.D.; Weinberger, R.P.; Cochran, B.; Doctrow, S.R.; Harry, J.; Melov, S. Endogenous mitochondrial oxidative stress: Neurodegeneration, proteomic analysis, specific respiratory chain defects, and efficacious antioxidant therapy in superoxide dismutase 2 null mice. J. Neurochem. 2004, 88, 657-667. [CrossRef] [PubMed]

147. Tyagi, R.; Shahani, N.; Gorgen, L.; Ferretti, M.; Pryor, W.; Chen, P.Y.; Swarnkar, S.; Worley, P.F.; Karbstein, K.; Snyder, S.H.; et al. RHEB inhibits protein synthesis by activating the PERK-eIF2alpha signaling cascade. Cell Rep. 2015, 10, 684-693. [CrossRef] [PubMed]

148. Pryor, W.M.; Biagioli, M.; Shahani, N.; Swarnkar, S.; Huang, W.C.; Page, D.T.; MacDonald, M.E.; Subramaniam, S. Huntingtin promotes mTORC1 signaling in the pathogenesis of huntington's disease. Sci. Signal. 2014, 7, ra103. [CrossRef]

149. Lee, J.H.; Tecedor, L.; Chen, Y.H.; Monteys, A.M.; Sowada, M.J.; Thompson, L.M.; Davidson, B.L. Reinstating aberrant mTORC1 activity in huntington's disease mice improves disease phenotypes. Neuron 2015, 85, 303-315. [CrossRef]

150. Shahani, N.; Pryor, W.; Swarnkar, S.; Kholodilov, N.; Thinakaran, G.; Burke, R.E.; Subramaniam, S. RHEB gtpase regulates beta-secretase levels and amyloid beta generation. J. Biol. Chem. 2014, 289, 5799-5808. [CrossRef]

151. Gallo, G.; Letourneau, P.C. Axon guidance: Gtpases help axons reach their targets. Curr. Biol. 1998, 8, R80-R82. [CrossRef]

152. Flynn, K.C. The cytoskeleton and neurite initiation. Bioarchitecture 2013, 3, 86-109. [CrossRef] [PubMed]

153. Bradke, F.; Dotti, C.G. The role of local actin instability in axon formation. Science 1999, 283, $1931-1934$. [CrossRef] [PubMed]

154. Jiang, H.; Guo, W.; Liang, X.; Rao, Y. Both the establishment and the maintenance of neuronal polarity require active mechanisms: Critical roles of GSK-3 $\beta$ and its upstream regulators. Cell 2005, 120, 123-135. [CrossRef]

155. Guo, Y.; Liu, Z.; Chen, Y.-K.; Chai, Z.; Zhou, C.; Zhang, Y. Neurons with multiple axons have functional axon initial segments. Neurosci. Bull. 2017, 33, 641-652. [CrossRef]

156. Lange-Carter, C.; Johnson, G. Ras-dependent growth factor regulation of mek kinase in PC12 cells. Science 1994, 265, 1458-1461. [CrossRef]

157. Jaiswal, R.K.; Moodie, S.A.; Wolfman, A.; Landreth, G.E. The mitogen-activated protein kinase cascade is activated by b-raf in response to nerve growth factor through interaction with p21ras. Mol. Cell. Biol. 1994, 14, 6944-6953. [CrossRef]

158. Sarah, T.; Philip, C. Identification of a latent map kinase kinase kinase in PC12 cells as b-raf. FEBS Lett. 1994, 350, 13-18. [CrossRef]

159. Vaillancourt, R.R.; Gardner, A.M.; Johnson, G.L. B-raf-dependent regulation of the mek-1/mitogen-activated protein kinase pathway in PC12 cells and regulation by cyclic amp. Mol. Cell. Biol. 1994, 14, 6522-6530. [CrossRef]

160. Bar-Sagi, D.; Feramisco, J.R. Microinjection of the ras oncogene protein into PC12 cells induces morphological differentiation. Cell 1985, 42, 841-848. [CrossRef]

161. Robinson, M.J.; Stippec, S.A.; Goldsmith, E.; White, M.A.; Cobb, M.H. A constitutively active and nuclear form of the map kinase ERK2 is sufficient for neurite outgrowth and cell transformation. Curr. Biol. 1998, 8 , 1141-1152. [CrossRef]

162. Warn-Cramer, B.J.; Lampe, P.D.; Kurata, W.E.; Kanemitsu, M.Y.; Loo, L.W.M.; Eckhart, W.; Lau, A.F. Characterization of the mitogen-activated protein kinase phosphorylation sites on the connexin-43 gap junction protein. J. Biol. Chem. 1996, 271, 3779-3786. [CrossRef] [PubMed]

163. Kanemitsu, M.Y.; Lau, A.F. Epidermal growth factor stimulates the disruption of gap junctional communication and connexin 43 phosphorylation independent of 12-0-tetradecanoylphorbol 13-acetate-sensitive protein kinase C: The possible involvement of mitogen-activated protein kinase. Mol. Biol. Cell 1993, 4, 837-848. [CrossRef] [PubMed]

164. Mamoru, S. Chromatographic resolution and characterization of a nerve growth factor-dependent kinase that phosphorylates microtubule-associated proteins 1 and 2 in PC12 cells. J. Neurochem. 1992, 59, 1263-1272. [CrossRef]

165. Sturgill, T.W.; Ray, L.B. Muscle proteins related to microtubule associated protein-2 are substrates for an insulin-stimulatable kinase. Biochem. Biophys. Res. Commun. 1986, 134, 565-571. [CrossRef] 
166. Drewes, G.; Lichtenberg-Kraag, B.; Döring, F.; Mandelkow, E.M.; Biernat, J.; Goris, J.; Dorée, M.; Mandelkow, E. Mitogen activated protein (MAP) kinase transforms tau protein into an alzheimer-like state. EMBO J. 1992, 11, 2131-2138. [CrossRef] [PubMed]

167. Mitsushima, M.; Suwa, A.; Amachi, T.; Ueda, K.; Kioka, N. Extracellular signal-regulated kinase activated by epidermal growth factor and cell adhesion interacts with and phosphorylates vinexin. J. Biol. Chem. 2004, 279, 34570-34577. [CrossRef]

168. Atwal, J.K.; Massie, B.; Miller, F.D.; Kaplan, D.R. The trkb-shc site signals neuronal survival and local axon growth via mek and pi3-kinase. Neuron 2000, 27, 265-277. [CrossRef]

169. Mills, J.; Digicaylioglu, M.; Legg, A.T.; Young, C.E.; Young, S.S.; Barr, A.M.; Fletcher, L.; O'Connor, T.P.; Dedhar, S. Role of integrin-linked kinase in nerve growth factor-stimulated neurite outgrowth. J. Neurosci. 2003, 23, 1638-1648. [CrossRef]

170. Zhou, F.-Q.; Zhou, J.; Dedhar, S.; Wu, Y.-H.; Snider, W.D. Ngf-induced axon growth is mediated by localized inactivation of GSK-3 $\beta$ and functions of the microtubule plus end binding protein apc. Neuron 2004, 42, 897-912. [CrossRef]

171. Nishimura, T.; Fukata, Y.; Kato, K.; Yamaguchi, T.; Matsuura, Y.; Kamiguchi, H.; Kaibuchi, K. Crmp-2 regulates polarized numb-mediated endocytosis for axon growth. Nat. Cell Biol. 2003, 5, 819. [CrossRef] [PubMed]

172. Arimura, N.; Menager, C.; Fukata, Y.; Kaibuchi, K. Role of crmp-2 in neuronal polarity. J. Neurobiol. 2004, 58, 34-47. [CrossRef] [PubMed]

173. Ridley, A.J. Rho gtpases and actin dynamics in membrane protrusions and vesicle trafficking. Trends Cell Biol. 2006, 16, 522-529. [CrossRef] [PubMed]

174. Bregman, B.; Goldberger, M. Anatomical plasticity and sparing of function after spinal cord damage in neonatal cats. Science 1982, 217, 553-555. [CrossRef] [PubMed]

175. Kunkel-Bagden, E.; Dai, H.-N.; Bregman, B.S. Recovery of function after spinal cord hemisection in newborn and adult rats: Differential effects on reflex and locomotor function. Exp. Neurol. 1992, 116, 40-51. [CrossRef]

176. David, S.; Aguayo, A. Axonal elongation into peripheral nervous system "bridges" after central nervous system injury in adult rats. Science 1981, 214, 931-933. [CrossRef] [PubMed]

177. Fawcett, J.W. The paper that restarted modern central nervous system axon regeneration research. Trends Neurosci. 2018, 41, 239-242. [CrossRef] [PubMed]

178. Filbin, M.T. Recapitulate development to promote axonal regeneration: Good or bad approach? Philos. Trans. R. Soc. B Biol. Sci. 2006, 361, 1565-1574. [CrossRef]

179. Lindsay, R.M. Neuron saving schemes. Nature 1995, 373, 289. [CrossRef]

180. Oppenheim, R.W. Neurotrophic survival molecules for motoneurons: An embarrassment of riches. Neuron 1996, 17, 195-197. [CrossRef]

181. Namikawa, K.; Honma, M.; Abe, K.; Takeda, M.; Mansur, K.; Obata, T.; Miwa, A.; Okado, H.; Kiyama, H. $\mathrm{Akt} /$ protein kinase $\mathrm{b}$ prevents injury-induced motoneuron death and accelerates axonal regeneration. J. Neurosci. 2000, 20, 2875-2886. [CrossRef] [PubMed]

182. Mahar, M.; Cavalli, V. Intrinsic mechanisms of neuronal axon regeneration. Nat. Rev. Neurosci. 2018, 19, 323-337. [CrossRef] [PubMed]

183. Dietz, V.; Schwab, M.E. From the rodent spinal cord injury model to human application: Promises and challenges. J. Neurotrauma 2017, 34, 1826-1830. [CrossRef] [PubMed]

184. Hollis, E.R.; Jamshidi, P.; Löw, K.; Blesch, A.; Tuszynski, M.H. Induction of corticospinal regeneration by lentiviral trkb-induced erk activation. Proc. Natl. Acad. Sci. USA 2009, 106, 7215-7220. [CrossRef] [PubMed]

185. Sapieha, P.S.; Hauswirth, W.W.; Di Polo, A. Extracellular signal-regulated kinases $1 / 2$ are required for adult retinal ganglion cell axon regeneration induced by fibroblast growth factor-2. J. Neurosci. Res. 2006, 83, 985-995. [CrossRef] [PubMed]

186. Kermer, P.; Digicaylioglu, M.H.; Kaul, M.; Zapata, J.M.; Krajewska, M.; Stenner-Liewen, F.; Takayama, S.; Krajewski, S.; Lipton, S.A.; Reed, J.C. BAG1 over-expression in brain protects against stroke. Brain Pathol. 2003, 13, 495-506. [CrossRef] [PubMed]

187. Pernet, V.; Hauswirth, W.W.; Di Polo, A. Extracellular signal-regulated kinase 1/2 mediates survival, but not axon regeneration, of adult injured central nervous system neurons in vivo. J. Neurochem. 2005, 93, 72-83. [CrossRef] 
188. O’Donovan, K.J.; Ma, K.; Guo, H.; Wang, C.; Sun, F.; Han, S.B.; Kim, H.; Wong, J.K.; Charron, J.; Zou, H.; et al. B-raf kinase drives developmental axon growth and promotes axon regeneration in the injured mature CNS. J. Exp. Med. 2014, 211, 801-814. [CrossRef]

189. Park, K.K.; Liu, K.; Hu, Y.; Smith, P.D.; Wang, C.; Cai, B.; Xu, B.; Connolly, L.; Kramvis, I.; Sahin, M.; et al. Promoting axon regeneration in the adult CNS by modulation of the pten/mtor pathway. Science 2008, 322, 963-966. [CrossRef]

190. Liu, K.; Lu, Y.; Lee, J.K.; Samara, R.; Willenberg, R.; Sears-Kraxberger, I.; Tedeschi, A.; Park, K.K.; Jin, D.; Cai, B.; et al. PTEN deletion enhances the regenerative ability of adult corticospinal neurons. Nat. Neurosci. 2010, 13, 1075. [CrossRef]

191. Christie, K.J.; Webber, C.A.; Martinez, J.A.; Singh, B.; Zochodne, D.W. Pten inhibition to facilitate intrinsic regenerative outgrowth of adult peripheral axons. J. Neurosci. 2010, 30, 9306-9315. [CrossRef] [PubMed]

192. Abe, N.; Borson, S.H.; Gambello, M.J.; Wang, F.; Cavalli, V. Mammalian target of rapamycin (mTOR) activation increases axonal growth capacity of injured peripheral nerves. J. Biol. Chem. 2010, 285, 28034-28043. [CrossRef] [PubMed]

193. Koh, C.G. Rho gtpases and their regulators in neuronal functions and development. Neurosignals 2007, 15, 228-237. [CrossRef] [PubMed]

194. Auer, M.; Schweigreiter, R.; Hausott, B.; Thongrong, S.; Höltje, M.; Just, I.; Bandtlow, C.; Klimaschewski, L. Rho-independent stimulation of axon outgrowth and activation of the erk and akt signaling pathways by c3 transferase in sensory neurons. Front. Cell. Neurosci. 2012, 6, 43. [CrossRef] [PubMed]

195. Rishal, I.; Fainzilber, M. Axon-soma communication in neuronal injury. Nat. Rev. Neurosci. 2013, 15, 32. [CrossRef] [PubMed]

196. Cai, D.; Qiu, J.; Cao, Z.; McAtee, M.; Bregman, B.S.; Filbin, M.T. Neuronal cyclic amp controls the developmental loss in ability of axons to regenerate. J. Neurosci. 2001, 21, 4731-4739. [CrossRef] [PubMed]

197. Gao, Y.; Deng, K.; Hou, J.; Bryson, J.B.; Barco, A.; Nikulina, E.; Spencer, T.; Mellado, W.; Kandel, E.R.; Filbin, M.T. Activated creb is sufficient to overcome inhibitors in myelin and promote spinal axon regeneration in vivo. Neuron 2004, 44, 609-621. [CrossRef] [PubMed]

198. Ghosh-Roy, A.; Wu, Z.; Goncharov, A.; Jin, Y.; Chisholm, A.D. Calcium and cyclic amp promote axonal regeneration in Caenorhabditis elegans and require dlk-1 kinase. J. Neurosci. 2010, 30, 3175-3183. [CrossRef] [PubMed]

199. Grandpré, T.; Strittmatter, S.M. Nogo: A molecular determinant of axonal growth and regeneration. Neuroscientist 2001, 7, 377-386. [CrossRef] [PubMed]

200. Brochier, C.; Jones, J.I.; Willis, D.E.; Langley, B. Poly(adp-ribose) polymerase 1 is a novel target to promote axonal regeneration. Proc. Natl. Acad. Sci. USA 2015, 112, 15220-15225. [CrossRef] [PubMed]

201. Wang, X.; Sekine, Y.; Byrne, A.B.; Cafferty, W.B.J.; Hammarlund, M.; Strittmatter, S.M. Inhibition of poly-ADP-ribosylation fails to increase axonal regeneration or improve functional recovery after adult mammalian CNS injury. Eneuro 2016, 3. [CrossRef] [PubMed]

202. Kosmaczewski, S.G.; Han, S.M.; Han, B.; Irving Meyer, B.; Baig, H.S.; Athar, W.; Lin-Moore, A.T.; Koelle, M.R.; Hammarlund, M. RNA ligation in neurons by RtcB inhibits axon regeneration. Proc. Natl. Acad. Sci. USA 2015, 112, 8451-8456. [CrossRef] [PubMed]

203. Song, Y.; Sretavan, D.; Salegio, E.A.; Berg, J.; Huang, X.; Cheng, T.; Xiong, X.; Meltzer, S.; Han, C.; Nguyen, T.-T.; et al. Regulation of axon regeneration by the RNA repair and splicing pathway. Nat. Neurosci. 2015, 18, 817. [CrossRef] [PubMed]

204. Imielski, Y.; Schwamborn, J.C.; Lüningschrör, P.; Heimann, P.; Holzberg, M.; Werner, H.; Leske, O.; Püschel, A.W.; Memet, S.; Heumann, R.; et al. Regrowing the adult brain: Nf-kb controls functional circuit formation and tissue homeostasis in the dentate gyrus. PLoS ONE 2012, 7, e30838. [CrossRef] [PubMed]

205. Moore, D.L.; Goldberg, J.L. Multiple transcription factor families regulate axon growth and regeneration. Dev. Neurobiol. 2011, 71, 1186-1211. [CrossRef] [PubMed]

206. Kim, S.R.; Kareva, T.; Yarygina, O.; Kholodilov, N.; Burke, R.E. AAV transduction of dopamine neurons with constitutively active RHEB protects from neurodegeneration and mediates axon regrowth. Mol. Ther. 2012, 20, 275-286. [CrossRef] [PubMed] 
207. Wu, D.; Klaw, M.C.; Connors, T.; Kholodilov, N.; Burke, R.E.; Tom, V.J. Expressing constitutively active RHEB in adult neurons after a complete spinal cord injury enhances axonal regeneration beyond a chondroitinase-treated glial scar. J. Neurosci. 2015, 35, 11068-11080. [CrossRef]

208. Wu, D.; Klaw, M.C.; Connors, T.; Kholodilov, N.; Burke, R.E.; Côté, M.-P.; Tom, V.J. Combining constitutively active RHEB expression and chondroitinase promotes functional axonal regeneration after cervical spinal cord injury. Mol. Ther. 2017, 25, 2715-2726. [CrossRef]

209. Deisseroth, K. Optogenetics: 10 years of microbial opsins in neuroscience. Nat. Neurosci. 2015, 18, $1213-1225$. [CrossRef]

210. Liu, H.; Yu, X.; Li, K.; Klejnot, J.; Yang, H.; Lisiero, D.; Lin, C. Photoexcited cry2 interacts with cib1 to regulate transcription and floral initiation in arabidopsis. Science 2008, 322, 1535-1539. [CrossRef]

211. Kennedy, M.J.; Hughes, R.M.; Peteya, L.A.; Schwartz, J.W.; Ehlers, M.D.; Tucker, C.L. Rapid blue light induction of protein interactions in living cells. Nat. Methods 2010, 7, 973-975. [CrossRef] [PubMed]

212. Christie, J.M.; Salomon, M.; Nozue, K.; Wada, M.; Briggs, W.R. Lov (light, oxygen, or voltage) domains of the blue-light photoreceptor phototropin (nph1): Binding sites for the chromophore flavin mononucleotide. Proc. Natl. Acad. Sci. USA 1999, 96, 8779-8783. [CrossRef] [PubMed]

213. Ni, M.; Tepperman, J.M.; Quail, P.H. Binding of phytochrome b to its nuclear signalling partner pif3 is reversibly induced by light. Nature 1999, 400, 781-784. [CrossRef] [PubMed]

214. Shimizu-Sato, S.; Huq, E.; Tepperman, J.M.; Quail, P.H. A light-switchable gene promoter system. Nat. Biotechnol. 2002, 20, 1041-1044. [CrossRef] [PubMed]

215. Zhou, X.X.; Chung, H.K.; Lam, A.J.; Lin, M.Z. Optical control of protein activity by fluorescent protein domains. Science 2012, 338, 810-814. [CrossRef] [PubMed]

216. Tischer, D.; Weiner, O.D. Illuminating cell signalling with optogenetic tools. Nat. Rev. Mol. Cell Biol. 2014, 15, 551-558. [CrossRef] [PubMed]

217. Bugaj, L.J.; Choksi, A.T.; Mesuda, C.K.; Kane, R.S.; Schaffer, D.V. Optogenetic protein clustering and signaling activation in mammalian cells. Nat. Methods 2013, 10, 249-252. [CrossRef] [PubMed]

218. Wu, Y.I.; Frey, D.; Lungu, O.I.; Jaehrig, A.; Schlichting, I.; Kuhlman, B.; Hahn, K.M. A genetically encoded photoactivatable rac controls the motility of living cells. Nature 2009, 461, 104-108. [CrossRef] [PubMed]

219. Wang, X.; Chen, X.; Yang, Y. Spatiotemporal control of gene expression by a light-switchable transgene system. Nat. Methods 2012, 9, 266-269. [CrossRef]

220. Strickland, D.; Lin, Y.; Wagner, E.; Hope, C.M.; Zayner, J.; Antoniou, C.; Sosnick, T.R.; Weiss, E.L.; Glotzer, M. Tulips: Tunable, light-controlled interacting protein tags for cell biology. Nat. Methods 2012, 9, 379-384. [CrossRef]

221. Guntas, G.; Hallett, R.A.; Zimmerman, S.P.; Williams, T.; Yumerefendi, H.; Bear, J.E.; Kuhlman, B. Engineering an improved light-induced dimer (ilid) for controlling the localization and activity of signaling proteins. Proc. Natl. Acad. Sci. USA 2015, 112, 112-117. [CrossRef] [PubMed]

222. Zimmerman, S.P.; Hallett, R.A.; Bourke, A.M.; Bear, J.E.; Kennedy, M.J.; Kuhlman, B. Tuning the binding affinities and reversion kinetics of a light inducible dimer allows control of transmembrane protein localization. Biochemistry 2016, 55, 5264-5271. [CrossRef] [PubMed]

223. Hallett, R.A.; Zimmerman, S.P.; Yumerefendi, H.; Bear, J.E.; Kuhlman, B. Correlating in vitro and in vivo activities of light-inducible dimers: A cellular optogenetics guide. ACS Synth. Biol. 2016, 5, 53-64. [CrossRef] [PubMed]

224. Levskaya, A.; Weiner, O.D.; Lim, W.A.; Voigt, C.A. Spatiotemporal control of cell signalling using a light-switchable protein interaction. Nature 2009, 461, 997-1001. [CrossRef] [PubMed]

225. Gambetta, G.A.; Lagarias, J.C. Genetic engineering of phytochrome biosynthesis in bacteria. Proc. Natl. Acad. Sci. USA 2001, 98, 10566-10571. [CrossRef] [PubMed]

226. Muller, K.; Engesser, R.; Timmer, J.; Nagy, F.; Zurbriggen, M.D.; Weber, W. Synthesis of phycocyanobilin in mammalian cells. Chem. Commun. 2013, 49, 8970-8972. [CrossRef] [PubMed]

227. Zhang, K.; Cui, B. Optogenetic control of intracellular signaling pathways. Trends Biotechnol. 2015, 33, 92-100. [CrossRef] [PubMed]

228. Zimmerman, S.P.; Asokan, S.B.; Kuhlman, B.; Bear, J.E. Cells lay their own tracks-Optogenetic cdc42 activation stimulates fibronectin deposition supporting directed migration. J. Cell Sci. 2017, 130, 2971-2983. [CrossRef] [PubMed] 
229. Toettcher, J.E.; Weiner, O.D.; Lim, W.A. Using optogenetics to interrogate the dynamic control of signal transmission by the ras/erk module. Cell 2013, 155, 1422-1434. [CrossRef]

230. Zhang, K.; Duan, L.; Ong, Q.; Lin, Z.; Varman, P.M.; Sung, K.; Cui, B. Light-mediated kinetic control reveals the temporal effect of the raf/mek/erk pathway in PC12 cell neurite outgrowth. PLoS ONE 2014, 9, e92917. [CrossRef] [PubMed]

231. Aoki, K.; Kumagai, Y.; Sakurai, A.; Komatsu, N.; Fujita, Y.; Shionyu, C.; Matsuda, M. Stochastic erk activation induced by noise and cell-to-cell propagation regulates cell density-dependent proliferation. Mol. Cell 2013, 52, 529-540. [CrossRef] [PubMed]

232. Aoki, K.; Kondo, Y.; Naoki, H.; Hiratsuka, T.; Itoh, R.E.; Matsuda, M. Propagating wave of erk activation orients collective cell migration. Dev. Cell 2017, 43, 305-317.e305. [CrossRef] [PubMed]

233. Wend, S.; Wagner, H.J.; Muller, K.; Zurbriggen, M.D.; Weber, W.; Radziwill, G. Optogenetic control of protein kinase activity in mammalian cells. ACS Synth. Biol. 2014, 3, 280-285. [CrossRef] [PubMed]

234. Dine, E.; Gil, A.A.; Uribe, G.; Brangwynne, C.P.; Toettcher, J.E. Protein phase separation provides long-term memory of transient spatial stimuli. Cell Syst. 2018, 6, 655-663.e655. [CrossRef] [PubMed]

235. Goglia, A.G.; Wilson, M.Z.; DiGiorno, D.B.; Toettcher, J.E. Optogenetic control of ras/erk signaling using the phy-pif system. Methods Mol. Biol. 2017, 1636, 3-20. [CrossRef] [PubMed]

236. Chatelle, C.V.; Hovermann, D.; Muller, A.; Wagner, H.J.; Weber, W.; Radziwill, G. Optogenetically controlled raf to characterize braf and craf protein kinase inhibitors. Sci. Rep. 2016, 6, 23713. [CrossRef]

237. Krishnamurthy, V.V.; Khamo, J.S.; Mei, W.; Turgeon, A.J.; Ashraf, H.M.; Mondal, P.; Patel, D.B.; Risner, N.; Cho, E.E.; Yang, J.; et al. Reversible optogenetic control of kinase activity during differentiation and embryonic development. Development 2016, 143, 4085-4094. [CrossRef]

238. Cantley, L.C. The phosphoinositide 3-kinase pathway. Science 2002, 296, 1655-1657. [CrossRef]

239. Toettcher, J.E. Light-based feedback for controlling intracellular signaling dynamics. Nat. Methods 2011, 8, 837-839. [CrossRef]

240. Kakumoto, T.; Nakata, T. Optogenetic control of pip3: Pip3 is sufficient to induce the actin-based active part of growth cones and is regulated via endocytosis. PLoS ONE 2013, 8, e70861. [CrossRef]

241. Idevall-Hagren, O.; Dickson, E.J.; Hille, B.; Toomre, D.K.; De Camilli, P. Optogenetic control of phosphoinositide metabolism. Proc. Natl. Acad. Sci. USA 2012, 109, E2316-E2323. [CrossRef] [PubMed]

242. Kim, N.; Kim, J.; Lee, M.; Kim, C.; Chang, K.-Y.; Heo, W. Spatiotemporal control of fibroblast growth factor receptor signals by blue light. Chem. Biol. 2014, 21, 903-912. [CrossRef] [PubMed]

243. Grusch, M.; Schelch, K.; Riedler, R.; Reichhart, E.; Differ, C.; Berger, W.; Ingles-Prieto, A.; Janovjak, H. Spatio-temporally precise activation of engineered receptor tyrosine kinases by light. EMBO J. 2014, 33, 1713-1726. [CrossRef] [PubMed]

244. Ono, K.; Suzuki, H.; Yamamoto, R.; Sahashi, H.; Takido, Y.; Sawada, M. Optogenetic control of cell differentiation in channelrhodopsin-2-expressing os3, a bipotential glial progenitor cell line. Neurochem. Int. 2017, 104, 49-63. [CrossRef] [PubMed]

245. Fischer, A.; Warscheid, B.; Weber, W.; Radziwill, G. Optogenetic clustering of cnk1 reveals mechanistic insights in raf and akt signalling controlling cell fate decisions. Sci. Rep. 2016, 6, 38155. [CrossRef] [PubMed]

246. Yazawa, M.; Sadaghiani, A.M.; Hsueh, B.; Dolmetsch, R.E. Induction of protein-protein interactions in live cells using light. Nat. Biotechnol. 2009, 27, 941-945. [CrossRef] [PubMed]

247. Beyer, H.M.; Naumann, S.; Weber, W.; Radziwill, G. Optogenetic control of signaling in mammalian cells. Biotechnol. J. 2015, 10, 273-283. [CrossRef]

248. Chen, S.; Weitemier, A.Z.; Zeng, X.; He, L.; Wang, X.; Tao, Y.; Huang, A.J.Y.; Hashimotodani, Y.; Kano, M.; Iwasaki, H.; et al. Near-infrared deep brain stimulation via upconversion nanoparticle-mediated optogenetics. Science 2018, 359, 679-684. [CrossRef]

249. Kanczler, J.M.; Sura, H.S.; Magnay, J.; Green, D.; Oreffo, R.O.; Dobson, J.P.; El Haj, A.J. Controlled differentiation of human bone marrow stromal cells using magnetic nanoparticle technology. Tissue Eng. Part A 2010, 16, 3241-3250. [CrossRef]

250. Seo, D.; Southard, K.M.; Kim, J.W.; Lee, H.J.; Farlow, J.; Lee, J.U.; Litt, D.B.; Haas, T.; Alivisatos, A.P.; Cheon, J.; et al. A mechanogenetic toolkit for interrogating cell signaling in space and time. Cell 2016, 165, 1507-1518. [CrossRef]

251. Stanley, S.A.; Sauer, J.; Kane, R.S.; Dordick, J.S.; Friedman, J.M. Remote regulation of glucose homeostasis in mice using genetically encoded nanoparticles. Nat. Med. 2015, 21, 92-98. [CrossRef] [PubMed] 
252. Van Bergeijk, P.; Adrian, M.; Hoogenraad, C.C.; Kapitein, L.C. Optogenetic control of organelle transport and positioning. Nature 2015, 518, 111-114. [CrossRef] [PubMed]

253. Gautier, M.; Dhennin-Duthille, I.; Ay, A.S.; Rybarczyk, P.; Korichneva, I.; Ouadid-Ahidouch, H. New insights into pharmacological tools to tr(i)p cancer up. Br. J. Pharmacol. 2014, 171, 2582-2592. [CrossRef] [PubMed]

254. Liu, Z.; Liu, Y.; Chang, Y.; Seyf, H.R.; Henry, A.; Mattheyses, A.L.; Yehl, K.; Zhang, Y.; Huang, Z.; Salaita, K. Nanoscale optomechanical actuators for controlling mechanotransduction in living cells. Nat. Methods 2016, 13, 143-146. [CrossRef] [PubMed]

255. Monzel, C. Magnetic control of cellular processes using biofunctional nanoparticles. Chem. Sci. 2017, 8, 7330-7338. [CrossRef] [PubMed]

256. Johnsen, S.; Lohmann, K.J. The physics and neurobiology of magnetoreception. Nat. Rev. Neurosci. 2005, 6, 703-712. [CrossRef] [PubMed]

257. Ritz, T.; Ahmad, M.; Mouritsen, H.; Wiltschko, R.; Wiltschko, W. Photoreceptor-based magnetoreception: Optimal design of receptor molecules, cells, and neuronal processing. J. R. Soc. Interface 2010, 7 (Suppl. 2), S135-S146. [CrossRef]

258. Pankhurst, Q.A.; Connolly, J.; Jones, S.; Dobson, J. Applications of magnetic nanoparticles in biomedicine. J. Phys. D Appl. Phys. 2003, 36, R167. [CrossRef]

259. Gupta, A.K.; Curtis, A.S. Surface modified superparamagnetic nanoparticles for drug delivery: Interaction studies with human fibroblasts in culture. J. Mater. Sci. Mater. Med. 2004, 15, 493-496. [CrossRef]

260. Griffete, N.; Fresnais, J.; Espinosa, A.; Wilhelm, C.; Bee, A.; Menager, C. Design of magnetic molecularly imprinted polymer nanoparticles for controlled release of doxorubicin under an alternative magnetic field in athermal conditions. Nanoscale 2015, 7, 18891-18896. [CrossRef]

261. Georgelin, T.; Bombard, S.; Siaugue, J.M.; Cabuil, V. Nanoparticle-mediated delivery of bleomycin. Angew. Chem. 2010, 49, 8897-8901. [CrossRef] [PubMed]

262. Dobson, J. Magnetic micro- and nano-particle-based targeting for drug and gene delivery. Nanomedicine 2006, 1, 31-37. [CrossRef] [PubMed]

263. Bulte, J.W.; Douglas, T.; Witwer, B.; Zhang, S.C.; Strable, E.; Lewis, B.K.; Zywicke, H.; Miller, B.; van Gelderen, P.; Moskowitz, B.M.; et al. Magnetodendrimers allow endosomal magnetic labeling and in vivo tracking of stem cells. Nat. Biotechnol. 2001, 19, 1141-1147. [CrossRef] [PubMed]

264. Lee, N.; Hyeon, T. Designed synthesis of uniformly sized iron oxide nanoparticles for efficient magnetic resonance imaging contrast agents. Chem. Soc. Rev. 2012, 41, 2575-2589. [CrossRef] [PubMed]

265. Dobson, J. Remote control of cellular behaviour with magnetic nanoparticles. Nat. Nanotechnol. 2008, 3, 139-143. [CrossRef] [PubMed]

266. Tajik, A.; Zhang, Y.; Wei, F.; Sun, J.; Jia, Q.; Zhou, W.; Singh, R.; Khanna, N.; Belmont, A.S.; Wang, N. Transcription upregulation via force-induced direct stretching of chromatin. Nature materials 2016, 15, 1287-1296. [CrossRef] [PubMed]

267. Lee, J.H.; Kim, J.W.; Levy, M.; Kao, A.; Noh, S.H.; Bozovic, D.; Cheon, J. Magnetic nanoparticles for ultrafast mechanical control of inner ear hair cells. ACS Nano 2014, 8, 6590-6598. [CrossRef]

268. Wheeler, M.A.; Smith, C.J.; Ottolini, M.; Barker, B.S.; Purohit, A.M.; Grippo, R.M.; Gaykema, R.P.; Spano, A.J.; Beenhakker, M.P.; Kucenas, S.; et al. Genetically targeted magnetic control of the nervous system. Nat. Neurosci. 2016, 19, 756-761. [CrossRef] [PubMed]

269. Rotherham, M.; El Haj, A.J. Remote activation of the wnt/beta-catenin signalling pathway using functionalised magnetic particles. PLoS ONE 2015, 10, e0121761. [CrossRef]

270. Tseng, P.; Judy, J.W.; Di Carlo, D. Magnetic nanoparticle-mediated massively-parallel mechanical modulation of single-cell behavior. Nat. Methods 2012, 9, 1113-1119. [CrossRef]

271. Riedinger, A.; Guardia, P.; Curcio, A.; Garcia, M.A.; Cingolani, R.; Manna, L.; Pellegrino, T. Subnanometer local temperature probing and remotely controlled drug release based on azo-functionalized iron oxide nanoparticles. Nano Lett. 2013, 13, 2399-2406. [CrossRef] [PubMed]

272. McKemy, D.D.; Neuhausser, W.M.; Julius, D. Identification of a cold receptor reveals a general role for trp channels in thermosensation. Nature 2002, 416, 52-58. [CrossRef]

273. Premkumar, L.S.; Abooj, M. Trp channels and analgesia. Life Sci. 2013, 92, 415-424. [CrossRef] [PubMed]

274. Song, C.W.; Park, H.; Griffin, R.J. Theoretical and experimental basis of hyperthermia. In Thermotherapy for Neoplasia, Inflammation, and Pain; Springer: Berlin/Heidelberg, Germany, 2001; pp. 394-407. 
275. Huang, H.; Delikanli, S.; Zeng, H.; Ferkey, D.M.; Pralle, A. Remote control of ion channels and neurons through magnetic-field heating of nanoparticles. Nat. Nanotechnol. 2010, 5, 602-606. [CrossRef] [PubMed]

276. Chen, R.; Romero, G.; Christiansen, M.G.; Mohr, A.; Anikeeva, P. Wireless magnetothermal deep brain stimulation. Science 2015, 347, 1477-1480. [CrossRef]

277. Stanley, S.A.; Gagner, J.E.; Damanpour, S.; Yoshida, M.; Dordick, J.S.; Friedman, J.M. Radio-wave heating of iron oxide nanoparticles can regulate plasma glucose in mice. Science 2012, 336, 604-608. [CrossRef] [PubMed]

278. Stanley, S.A.; Kelly, L.; Latcha, K.N.; Schmidt, S.F.; Yu, X.; Nectow, A.R.; Sauer, J.; Dyke, J.P.; Dordick, J.S.; Friedman, J.M. Bidirectional electromagnetic control of the hypothalamus regulates feeding and metabolism. Nature 2016, 531, 647-650. [CrossRef]

279. Mannix, R.J.; Kumar, S.; Cassiola, F.; Montoya-Zavala, M.; Feinstein, E.; Prentiss, M.; Ingber, D.E. Nanomagnetic actuation of receptor-mediated signal transduction. Nat. Nanotechnol. 2008, 3, 36-40. [CrossRef]

280. Bharde, A.A.; Palankar, R.; Fritsch, C.; Klaver, A.; Kanger, J.S.; Jovin, T.M.; Arndt-Jovin, D.J. Magnetic nanoparticles as mediators of ligand-free activation of egfr signaling. PLoS ONE 2013, 8, e68879. [CrossRef]

281. Cho, M.H.; Lee, E.J.; Son, M.; Lee, J.H.; Yoo, D.; Kim, J.W.; Park, S.W.; Shin, J.S.; Cheon, J. A magnetic switch for the control of cell death signalling in in vitro and in vivo systems. Nat. Mater. 2012, 11, 1038-1043. [CrossRef]

282. Lisse, D.; Monzel, C.; Vicario, C.; Manzi, J.; Maurin, I.; Coppey, M.; Piehler, J.; Dahan, M. Engineered ferritin for magnetogenetic manipulation of proteins and organelles inside living cells. Adv. Mater. 2017, 29. [CrossRef] [PubMed]

283. Etoc, F.; Vicario, C.; Lisse, D.; Siaugue, J.M.; Piehler, J.; Coppey, M.; Dahan, M. Magnetogenetic control of protein gradients inside living cells with high spatial and temporal resolution. Nano Lett. 2015, 15, 3487-3494. [CrossRef] [PubMed]

284. Rauch, J.; Kolch, W.; Mahmoudi, M. Cell type-specific activation of akt and erk signaling pathways by small negatively-charged magnetic nanoparticles. Sci. Rep. 2012, 2, 868. [CrossRef] [PubMed]

285. Etoc, F.; Lisse, D.; Bellaiche, Y.; Piehler, J.; Coppey, M.; Dahan, M. Subcellular control of rac-gtpase signalling by magnetogenetic manipulation inside living cells. Nat. Nanotechnol. 2013, 8, 193-198. [CrossRef] [PubMed]

286. Hoffmann, C.; Mazari, E.; Lallet, S.; Le Borgne, R.; Marchi, V.; Gosse, C.; Gueroui, Z. Spatiotemporal control of microtubule nucleation and assembly using magnetic nanoparticles. Nat. Nanotechnol. 2013, 8, 199-205. [CrossRef] [PubMed]

287. Takahashi, K.; Tanabe, K.; Ohnuki, M.; Narita, M.; Ichisaka, T.; Tomoda, K.; Yamanaka, S. Induction of pluripotent stem cells from adult human fibroblasts by defined factors. Cell 2007, 131, 861-872. [CrossRef] [PubMed]

288. Pfisterer, U.; Kirkeby, A.; Torper, O.; Wood, J.; Nelander, J.; Dufour, A.; Björklund, A.; Lindvall, O.; Jakobsson, J.; Parmar, M. Direct conversion of human fibroblasts to dopaminergic neurons. Proc. Natl. Acad. Sci. USA 2011, 108, 10343-10348. [CrossRef]

289. Makwana, M.; Serchov, T.; Hristova, M.; Bohatschek, M.; Gschwendtner, A.; Kalla, R.; Liu, Z.; Heumann, R.; Raivich, G. Regulation and function of neuronal gtp-ras in facial motor nerve regeneration. J. Neurochem. 2009, 108, 1453-1463. [CrossRef]

290. Kikuchi, T.; Morizane, A.; Doi, D.; Magotani, H.; Onoe, H.; Hayashi, T.; Mizuma, H.; Takara, S.; Takahashi, R.; Inoue, H.; et al. Human ips cell-derived dopaminergic neurons function in a primate parkinson's disease model. Nature 2017, 548, 592. [CrossRef]

291. Barker, R.A.; Parmar, M.; Studer, L.; Takahashi, J. Human trials of stem cell-derived dopamine neurons for parkinson's disease: Dawn of a new era. Cell Stem Cell 2017, 21, 569-573. [CrossRef]

292. Dinca, A.; Chien, W.M.; Chin, M.T. Intracellular delivery of proteins with cell-penetrating peptides for therapeutic uses in human disease. Int. J. Mol. Sci. 2016, 17, 263. [CrossRef] [PubMed]

293. Paliga, D.; Raudzus, F.; Leppla, S.H.; Heumann, R.; Neumann, S. Lethal factor domain-mediated delivery of nurr1 transcription factor enhances tyrosine hydroxylase activity and protects from neurotoxin-induced degeneration of dopaminergic cells. Mol. Neurobiol. 2018, 1-11. [CrossRef] [PubMed]

(C) 2018 by the authors. Licensee MDPI, Basel, Switzerland. This article is an open access article distributed under the terms and conditions of the Creative Commons Attribution (CC BY) license (http:/ / creativecommons.org/licenses/by/4.0/). 